\title{
Coisa julgada inconstitucional na teoria geral do direito e o Novo Código de Processo Civil ${ }^{1}$
}

\section{Juliano Taveira Bernardes}

Juiz Federal. Mestre em "Direito e Estado" pela Universidade de Brasília (UnB), com pósgraduação "lato sensu" pela Faculdade de Direito pela Universidade Federal de Goiás (UFG). É professor convidado dos cursos de pós-graduação "lato sensu" de Direito Constitucional e Direito Tributário da Faculdade de Direito da UFG. Autor, entre outras publicações, dos livros "Controle abstrato de constitucionalidade: elementos materiais e princípios processuais" (Saraiva, 2004) e "Efeitos das normas constitucionais no sistema normativo brasileiro" (Sergio Antonio Fabris Editor, 2002). Coautor da obra "Direito constitucional", Tomo I (JusPodivm, 5. edição, 2015) e Tomo II (JusPodivm, 4. edição, 2015) e do livro "Direito Constitucional I" da coleção Saberes do Direito (Saraiva, 2012). Foi Promotor de Justiça (1996/97), Juiz de Direito (1997/98) e Professor Assistente da Faculdade de Direito da Universidade Federal de Goiás (2005/2012). E-mail: jtbernardes@yahoo.com.br

\section{Resumo}

Analisa o papel inovador das decisões judiciais nos sistemas jurídicos, bem como a coisa julgada inconstitucional e suas relações de existência, validade e aplicabilidade normativas. Conclui que uma decisão judicial inconstitucional é ato existente, embora inválido, que se incorpora ao sistema normativo por força de metanorma específica que Ihe dá estabilidade normativa (art. 5ㅇ, XXXVI, da Constituição). Assim, a autoridade da coisa julgada decorrente de decisão judicial inconstitucional mantém-se aplicável até que seja desconstituída, pelos meios processuais próprios, no tempo e modo devidos.

Palavras-chave

Sistemas normativos; Coisa julgada inconstitucional; Inexistência; Invalidade; Aplicabilidade.

1 Versão ampliada e atualizada, conforme o NCPC, do texto originalmente publicado na revista Interesse Público - IP, Belo Horizonte, ano 12, n. 60, p. 161-190, mar./abr. 2010. 


\title{
Unconstitutionality res judicata in Law Theory and the New Brazilian Code of Civil Procedure
}

\begin{abstract}
This study analyzes the innovative role of judicial decisions in normative systems, including the unconstitutionality res iudicata and its relations of normative existence, validity and applicability. It concludes that an unconstitutional judical decision is an existent act, but a invalid one, which is incorporated into the Brasilian normative system under a specifc metanorm that gives it normative stability (Constitution, art. 5ㅇ, XXXVI). Then, the authority of res iudicata arising from unconstitutional judicial decision remains applicable until it has not been rescinded by proper procedural remedies, in time and due order.

The study also examines some constitutional principles applicable in repealing unconstitutional res iudicata, besides rescissory instruments provided by the new Brazilian Code of Civil Procedure - NCPC.
\end{abstract}

\section{Keywords}

Nomative systems; Unconstitutional res iudicata; Non-existence; Invalidity; Applicability.

\section{Sumário}

I - Apresentação. II - Sistemas jurídicos. 1. Sistemas normativos jurídicos. 2. Caráter estático e dinâmico dos sistemas jurídicos. 3. Pressupostos de desenvolvimento dos sistemas jurídicos. 4. Existência das normas jurídicas. 5. Validade das normas jurídicas. 6. Inconstitucionalidade: caso de inexistência ou de invalidade? 7. Existência/pertinência e validade vs. aplicabilidade normativas. III - Decisões judiciais e sistemas jurídicos. 1. Juízes "criam" direito? 2. Decisão judicial e "criação" de normas individuais. IV - Coisa julgada inconstitucional. 1. Definições prévias. 2. Inconstitucionalidade e coisa julgada. 3. Coisa julgada inconstitucional: inexistência ou invalidade? 4. Posição do STF. 5. Princípios constitucionais aplicáveis em matéria de desconstituição da coisa julgada inconstitucional. V - Instrumentos de desconstituição da coisa julgada inconstitucional no NCPC: breves comentários. 1. Sistema anterior ao NCPC. 1.1. Ação rescisória. 1.2. Embargos/impugnação rescisórios à execução. 2. Sistema do NCPC. 2.1. Ação rescisória. 2.2. Embargos/impugnação rescisórios à execução. VI - Referências bibliográficas.

\section{I - Apresentação}

O problema da coisa julgada inconstitucional desperta crescente atenção, sobretudo de processualistas. Todavia, embora o instituto da coisa julgada seja mesmo eminentemente processual, as discussões a respeito, quando envolvem questões de desconformidade constitucional, não podem fazer-se trancafiadas no campo do direito processual. Devem ser acompanhadas do exame de temas relacionados à teoria geral do direito e, obviamente, ao direito constitucional. Sem isso, contrassensos e equívocos são inevitáveis, até mesmo por parte de renomados nomes do processo civil. 
O desenvolvimento deste estudo é feito em quatro partes. Na primeira, serão feitas considerações resumidas sobre a definição e o funcionamento dos sistemas jurídicos. Na segunda, sobre o papel inovador das decisões judiciais nos sistemas jurídicos. $\mathrm{Na}$ terceira, sobre a coisa julgada inconstitucional e suas relações de existência e de validade normativas, bem como acerca dos princípios constitucionais aplicáveis em matéria de desconstituição da coisa julgada inconstitucional. Por fim, na quarta, sobre os instrumentos de desconstituição da coisa julgada inconstitucional no NCPC 2 .

\section{II - Sistemas Jurídicos}

\section{Sistemas normativos jurídicos}

"Sistema" significa reunião de elementos distintos e relacionados entre si, conforme dois requisitos: ordem e unidade ${ }^{3}$. Nos sistemas normativos, os elementos que os compõem são, basicamente, as normas (normas morais, sociais, religiosas, jurídicas) ${ }^{4}$. Já no caso dos sistemas normativos jurídicos, os elementos são normas também jurídicas - i.e., o produto da interpretação de formulações linguísticas que, produzidas num contexto institucionalizado, proíbem, ordenam ou permitem determinadas condutas humanas ${ }^{5}$.

2 Por questão de espaço, porém, optou-se por não abordar o problema da possibilidade de modulação temporal na impugnação à coisa julgada inconstitucional. Sobre o assunto, v. BERNARDES, Juliano Taveira. "Viradas" de jurisprudência do STF e suas repercussões em casos similares. In: NOVELINO, Marcelo (org.) et al. Leituras complementares de direito constitucional: controle de constitucionalidade. 3a ed. ampl. rev. atual. Salvador: JusPodivm, 2010b, p. 177-226.

${ }^{3}$ Segundo CANARIS, para caracterizar um sistema normativo, é preciso haver ordenação e unidade. A ordem sistêmica do direito provém da adstrição dos agentes políticos à exigência de proceder com adequação (regra da adequação valorativa), isto é, de acordo com o reconhecido postulado de justiça segundo o qual se deve tratar o igual de modo igual, e o diferente de forma diferente, à medida da diferença entre eles. Já a unidade radica na preocupação em garantir a ausência de contradições da ordem jurídica, de forma a realizar a chamada "tendência generalizadora" da justiça. Cf. CANARIS, Claus-Wilhelm. Pensamento sistemático e conceito de sistema na ciência do direito. Trad. A. Menezes Cordeiro. 3a ed. Lisboa: Fundação Calouste Gulbekian. 2002, p. 14 e segs.

${ }^{4} \mathrm{O}$ texto referiu-se à composição dos sistemas normativos fundada "basicamente" em normas para deixar claro que não são compostos apenas por normas. Deles fazem parte, ainda, critérios utilizados para definir objetos relevantes aos sistemas (para alguns, normas definitórias). Exemplo: 0 $\S 1$ o do artigo 18 da Constituição de 1988 dispõe: "Brasília é a Capital Federal." Não há aí nenhum comando normativo, senão uma definição que assume alguma importância para o sistema normativo brasileiro, como, v.g., para esclarecer a localização da sede do Governo Federal (ver inciso VII do art. 48 da mesma Constituição).

5 Como ensina BULYGIN e MENDONCA, os "problemas estruturais dos sistemas jurídicos (incompletude, incoerência e redundância) só podem ser elevados ao nível das normas, é dizer, das formulações normativas interpretadas e, por tanto, dotadas de um significado definido" (BULYGIN, Eugenio; MENDONCA, Daniel. Normas y sistemas normativos. Madrid: Marcial Pons, 2005, p. 44). No mesmo sentido, GUASTINI critica a concepção de ordenamento jurídico composto por normas dissociadas da interpretação. Em resumo, diz que "desejando representar os ordenamentos jurídicos como conjuntos de normas, a rigor ocorreria rever as noções correntes de ato normativo e

Revista Publicum

Rio de Janeiro, v. 3, n. 1, 2017, p. 307-351.

http://www.e-publicacoes.uerj.br/index.php/publicum

DOI: $10.12957 /$ publicum.2017.29464 
Contudo, se os sistemas jurídicos são conjunto "ordenado" de normas jurídicas, devem abranger não só as normas propriamente ditas, como também as normas que tratam dos próprios critérios pelos quais outras normas são ordenadas e conectadas entre $\mathrm{si}^{6}$. Trata-se das metanormas (para alguns, "postulados normativos"), que funcionam como elementos estruturais dos sistemas jurídicos, cuja função é disciplinar a organização e a aplicação de normas por meio de critérios normativos ${ }^{7}$.

\section{Caráter estático e dinâmico dos sistemas jurídicos}

Segundo KELSEN, conforme são extraídas normas particulares a partir de normas gerais que deles façam parte, os sistemas normativos podem ser classificados como estáticos ou dinâmicos ${ }^{8}$. Estáticos são os sistemas que permitem extrair normas de outras normas por meio de simples operações lógicas, ou seja, à base de conclusões que partam “do geral para o particular"9; e dinâmicos são os sistemas que atribuem poder (competência) a uma determinada autoridade para editar outras normas que se somarão ao sistema, mas com conteúdo diverso daquele das normas pré-existentes. Para KELSEN, os sistemas jurídicos são "essencialmente" dinâmicos ${ }^{10}$.

de fonte de direito. Em particular, no grupo dos atos normativos deveria estar inclusa também a interpretação. Porque a legislação produz não propriamente normas, mas somente disposições, textos normativos: as normas nascem não já da legislação, mas, sobretudo, da combinação de legislação e interpretação" (GUASTINI, Riccardo. Teoria e dogmatica delle fonti. Milano: Giuffrè, 1998, p. 138, rodapé).

${ }^{6}$ Como ensinam BULYGIN e MENDONCA, se "o status normativo de uma ação pode mudar como resultado de uma ordenação diferente do mesmo conjunto de normas, o mesmo conjunto pode dar lugar a sistemas diferentes, se há sido ordenado de forma distinta" (Normas y sistemas..., p. 79).

7 Exemplos de metanormas são os critérios de resolução de antinomia normativa, tais como o hierárquico (lex superior derogat inferiori), o cronológico (lex posterior derogat priori) e o da especialidade (lex specialis derogat generali), além de outras metanormas, como, v.g., as que tratam do início da vigência das normas, as que impedem a retroatividade normativa, os princípios da igualdade material e da proporcionalidade etc.

${ }^{8}$ KELSEN referiu-se à natureza do fundamento de validade das normas de cada sistema normativo. Assim, o modo com que normas eram obtidas (deduzidas) umas das outras foi explicado como relações de validade estáticas ou dinâmicas (KELSEN, Hans. Teoria pura do direito. Trad. João Baptista Machado. 6a ed. Coimbra: Armênio Amado, 1984, p. 269 e segs.).

${ }^{9}$ Logo, quando de uma norma de conteúdo genérico seja possível obter uma ou mais normas de conteúdo particular, mediante raciocínios de dedução lógica, trata-se de um sistema normativo estático. KELSEN exemplifica: da norma que impõe a veracidade, extraem-se logicamente as normas que proíbem mentir e fraudar e a que impõe a observância dos compromissos feitos, todas elas obtidas por meio de simples deduções lógicas. Para KELSEN, a moral é exemplo de sistema normativo estático.

10 Nas palavras do autor: "O sistema de normas que se apresenta como uma ordem jurídica tem essencialmente caráter dinâmico. Uma norma jurídica não vale porque tem um determinado conteúdo, quer dizer, porque o seu conteúdo pode ser deduzido pela via de um raciocínio lógico do de uma norma fundamental pressuposta, mas porque é criada por uma forma determinada - em última análise, por uma forma fixada por uma norma fundamental pressuposta. Por isso, e somente 
Todavia, das normas gerais produzidas por processos dinâmicos de criação normativa é possível extrair normas particulares por meio de deduções lógicas ${ }^{11}$. Assim, como nenhum sistema jurídico está resumido às normas que concedem competências para editar outras normas, de todos eles fazem parte, também - e ainda que implicitamente -, as normas extraídas de outras normas por meio de operações lógicas ${ }^{12}$. Essa a razão por que qualquer sistema normativo jurídico pode ser visto tanto de uma perspectiva estática, quanto dinâmica.

De outro lado, a identificação de algum sistema jurídico tem de partir de um ponto temporal determinado, pois os atos de promulgação e de derrogação de normas fazem com que o conjunto normativo original deixe de ser o mesmo ${ }^{13}$. Daí a necessidade de trabalhar com duas expressões distintas.

Nesse sentido, a expressão sistema jurídico significa conjunto de normas estaticamente considerado, a partir de um momento fixo no tempo (sistema jurídico

por isso, pertence ela à ordem jurídica cujas normas são criadas de conformidade com esta norma fundamental." (Teoria pura..., p. 273).

11 O próprio KELSEN disse: "O princípio estático e o princípio dinâmico estão reunidos numa e na mesma norma quando a norma fundamental pressuposta se limita, segundo o princípio dinâmico, a conferir poder a uma autoridade legisladora e esta mesma autoridade ou uma outra por ela instituída não só estabelecem normas pelas quais delegam noutras autoridades legisladoras mas também normas pelas quais se prescreve uma determinada conduta dos sujeitos subordinados às normas e das quais - como o particular do geral - pode ser deduzidas novas normas através de uma operação lógica." (Ibidem, p. 272.)

12 Para KELSEN, as relações lógicas que se estabelecem entre normas jurídicas são somente aquelas norteadas pela lógica clássica, sem que se possa falar numa "lógica normativa" (ver, especialmente, a obra póstuma Teoria geral das normas. Trad. José Florentino Duarte. Porto Alegre: Sergio Antonio Fabris Editor, 1986, p. 238 e segs.). Todavia, a maior parte da doutrina já não concorda com a teoria kelseniana a respeito. A partir de 1951, com o ensaio intitulado Deontic logic, escrito por von WRIGHT para a revista Mind, consolidou-se no meio acadêmico a importância e a utilidade da "lógica deôntica", i.e., o ramo da lógica que se dedica ao estudo dos raciocínios e operadores lógicos aplicáveis como instrumentos de argumentação racional das ciências normativas, especialmente a moral e o direito. De fato, não fossem os raciocínios desenvolvidos por uma lógica tipicamente normativa (deôntica), seria impossível explicar muitos dos fenômenos consensualmente aceitos pela ciência jurídica contemporânea. Como ensina WEINBERGER: "Devo dar alguns exemplos das dificuldades que surgiriam para a ciência jurídica analítica e especialmente para a concepção kelseniana da Teoria Pura do Direito se não houvesse relações lógico-normativas. Não se pode construir uma teoria a respeito de regras normativas desprovida de uma teoria estrutural relativa aos enunciados normativos e sem uma regra de subsunção. Seria irrelevante uma regra geral desprovida de consequências lógicas a respeito dos casos individuais que lhe sejam subsumíveis. A unidade racional de um sistema normativo é inconcebível sem critério lógico acerca da compatibilidade e incompatibilidade dos enunciados normativos. A ideia da concepção dinâmica do direito, no sentido de que a criação de novas normas leais está conectada a relações lógicas justificadoras, só tem sentido se existem consequências lógicas provenientes de normas válidas. A chamada derrogação material ensejada pelo princípio lex posterior derogat legi priori seria impossível se pudéssemos negar a existência de incompatibilidades lógicas entre normas, porque essa derrogação só tem lugar porque existe um conflito entre a norma antiga e a recente. Posso então concluir essas considerações com a tese: não há ciência jurídica analítica se não há uma lógica normativa." (WEINBERGER, Ota. A philosophical approach to norm logic. Ratio Juris, Bologna, vol. 14, n. 1, mar. 2001, p. 141.)

${ }^{13}$ BULYGIN e MENDONCA, op. cit., p. 45.

Revista Publicum

Rio de Janeiro, v. 3, n. 1, 2017, p. 307-351.

http://www.e-publicacoes.uerj.br/index.php/publicum

DOI: 10.12957/publicum.2017.29464 
"momentâneo" ou "sincrônico"). Assim, quando se fala em "sistema jurídico", a discussão gira em torno, sobretudo, do intitulado "direito vigente" - i.e., o conjunto momentâneo de normas que resulta da diferença entre o conjunto das normas explícita ou implicitamente promulgadas e o conjunto formado tanto pelas normas explícita ou implicitamente revogadas quanto pelas normas expulsas do sistema pela autoridade competente ${ }^{14}$. Já a expressão ordem jurídica (ou ordenamento jurídico) diz com a sequência de sistemas jurídicos através de certo período de tempo (sistema jurídico "diacrônico") $)^{15}$. Por isso, quando se fala em "ordem jurídica" ou em "ordenamento jurídico", sem outras adjetivações, é possível referir-se a todas as sequências momentâneas de sistemas jurídicos havidos num determinado Estado, incluindo sua última versão ${ }^{16}$. Ademais, num sentido bastante difundido, a ordem jurídica stricto sensu abrange somente a sequência de sistemas jurídicos momentâneos que sejam presididos por uma mesma constituição ${ }^{17}$.

\section{Pressupostos de desenvolvimento dos sistemas jurídicos}

Numa perspectiva estática, os sistemas jurídicos abrangem todas as consequências lógicas das normas que deles fazem parte. Logo, as relações estáticas entre os elementos dos sistemas jurídicos desenvolvem-se de acordo com o chamado critério da dedutibilidade lógica. As normas pertencentes a um sistema jurídico estático são somente aquelas que

\footnotetext{
${ }^{14}$ Sobre a expulsão dos sistemas jurídicos das normas invalidadas, v. itens 5 a 7 , infra.

15 Veja-se BULYGIN e MENDONCA, op. cit., p. 45; GUASTINI, Teoria e dogmatica..., p. 141-142; MORESO, José Juan; VILAJOSANA, Josep Maria. Introducción a la teoria del derecho. Madrid: Marcial Pons, 2004, p. 115.

${ }^{16}$ Conforme BULYGIN: "Se o sistema jurídico é concebido como um conjunto de objetos de algum tipo (por exemplo, um conjunto de regras estabelecidas ou jurídicas) e o conjunto é definido extensionalmente, então o sistema tem de se referir a um ponto temporal determinado, pois a partir de qualquer alteração causada por atos de criação ou de derrogação de normas, o conjunto deixa de ser o mesmo e se converte em outro distinto, com o qual voltamos a ter um conceito estático de sistema. Portanto, um sistema dinâmico não pode ser um conjunto de normas, mas sim uma família (é dizer, um conjunto) de conjuntos de normas, ou, mais precisamente, uma sequência temporal de conjuntos de normas. Isso nos levou a propor uma distinção terminológica entre sistema jurídico como um conjunto de normas e ordem jurídica como sequência de sistemas jurídicos (Alchourrón-Bulygin, 1976)." (BULYGIN, Eugenio. Algunas consideraciones sobre los sistemas jurídicos. Doxa. Cuadernos de Filosofía del Derecho, Alicante, n. 9, 1991, p. 259.)

17 Nas palavras de BULYGIN: "A noção de ordem jurídica esboçada aqui reflete um uso desta expressão. Para este conceito a identidade da ordem repousa na continuidade dos sistemas que a ele pertencem e isto quer dizer, em última instância, a continuidade da constituição, o que não implica sua imutabilidade, senão a legalidade do câmbio. Todo câmbio ilegal da constituição, é dizer, toda revolução jurídica conduz à ruptura da ordem jurídica e a nova constituição dará origem a uma nova ordem. Assim não somente a revolução russa de 1917, mas também a promulgação da Constituição espanhola de 1978 e a restauração da Constituição argentina em 1983 e qualquer golpe de Estado dão lugar a uma nova ordem jurídica. Neste sentido, "ordem jurídica» assim definida não se identifica com «direito estatal» ou "direito nacional»." (Algunas consideraciones..., p. 265).
} 
possam ser obtidas, mediante raciocínios logicamente consistentes, a partir de determinado conjunto finito de elementos que já integram o mesmo sistema. Toda norma obtida diferentemente não poderá ser considerada como elemento pertencente a esse sistema jurídico estático.

Já em perspectiva dinâmica, as relações de promulgação e de derrogação de normas, num dado sistema jurídico, desenvolvem-se de acordo com o chamado critério da legalidade, que se estabelece de acordo com o exercício da competência outorgada para produzir novas normas. Assim, embora o dinamismo do sistema possa alterar os elementos (normas) a partir dos quais outras normas poderiam ser extraídas pelo critério da dedutibilidade lógica, é preciso que eventuais alterações normativas (promulgação/derrogação de normas) se processem de acordo com critérios formais previstos pelo próprio sistema ${ }^{18}$. Nesses termos, segundo o critério da legalidade, um enunciado normativo pertencerá ao sistema se for editado (promulgado) por autoridade cuja competência para fazê-lo já estiver prevista em norma constante do mesmo sistema. Daí se dizer que o critério da legalidade é que estabelece as relações de unidade entre os sistemas normativos momentâneos considerados parte de uma mesma ordem jurídica ${ }^{19}$.

\section{Existência das normas jurídicas}

A noção mais aceita e difundida de existência normativa é aquela que relaciona o problema com a questão da pertinência da norma a um determinado sistema normativo ${ }^{20}$. Nesse sentido, a existência normativa remete a duas definições ${ }^{21}$. Fala-se em existência normativa "fatual" para aludir à qualidade de uma norma que tenha sido linguisticamente "formulada". Ocorre que, se essa acepção permite excluir as normas que não podem sequer ser inteligíveis como tal, alcança, por exemplo, as normas que constam em simples projetos de lei. Daí ser preferível relacionar o conceito de pertinência normativa à definição de existência "jurídica", a exigir que a norma, além de ter sido faticamente formulada, seja ainda "posta" - i.e., deliberada e emanada (promulgada). Nessa ordem de ideias, um sistema jurídico apresenta-se com um conjunto de normas não já válidas, mas que simplesmente existam juridicamente ${ }^{22}$.

${ }^{18}$ Empregando essa terminologia acerca dos aludidos critérios, v. MORESO e VILAJOSANA, op. cit., p. 97.

${ }^{19}$ MORESO e VILAJOSANA, op. cit., p. 116.

20 Por todos, cf. GUASTINI, Teoria..., p. 131.

${ }^{21}$ Ver GUASTINI, ibidem, p. 147-148 e 155-156.

22 GASTINI, ibidem, p. 147.

Revista Publicum

Rio de Janeiro, v. 3, n. 1, 2017, p. 307-351.

http://www.e-publicacoes.uerj.br/index.php/publicum

DOI: 10.12957/publicum.2017.29464 
Pois bem. Pelo conceito de existência como pertinência, salvo a norma-matriz do sistema ${ }^{23}$ - cuja existência é condicionada por outros fatores -, uma norma jurídica existe num dado sistema jurídico se tiver sido instituída (promulgada) "por autoridade normativa à primeira vista competente para criar esse tipo de norma" ${ }^{24}$. Isto é, a existência normativa pressupõe "uma relação entre quatro elementos: um sistema normativo, uma norma de competência desse sistema, um ato de criação normativa e uma norma criada neste ato 25 ." Por outras palavras, a norma existe quando promulgada por quem, conforme o critério da legalidade, seja competente para promulgar normas do mesmo tipo ${ }^{26}$.

Entretanto, seja num sistema jurídico estático, seja num dinâmico, pertencem ao sistema, ainda, as normas que, extraídas das normas já promulgadas mediante o critério da dedutibilidade lógica, se consideram implicitamente promulgadas. Logo, pertencem a uma ordem jurídica todas as normas obtidas conforme ou o critério da legalidade ou o critério da dedutibilidade lógica ${ }^{27}$.

Daí se concluir que a definição estática/sincrônica dos elementos integrantes de um sistema normativo dinâmico/diacrônico dependerá tanto da identificação de atos de promulgação/derrogação realizados pelas autoridades competentes quanto de questões lógicas, pois é necessário definir quais normas são agregadas ao sistema ou dele eliminadas como consequência dos atos de promulgação/derrogação normativa ${ }^{28}$.

${ }^{23}$ Todas as normas obtidas, seja pelo critério da dedutibilidade lógica, seja pelo critério da legalidade, são normas dependentes de outras. Porém, como explica BULYGIN, "os critérios de dedutibilidade e de legalidade são manifestamente insuficientes para dar conta da pertinência de todas as normas do sistema, pois pressupõem que o sistema já tenha normas, cuja pertinência não depende de nenhum dos dois critérios." (BULYGIN, Eugenio. Algunas consideraciones..., p. 262.) Logo, todo sistema jurídico precisa contar com uma classe de normas consideradas "independentes" (também conhecidas como "normas fundamentais" ou "normas de reconhecimento"), a partir das quais são obtidas as demais normas que compõem o sistema (pelo critério da dedutibilidade ou pelo critério da legalidade). Essa classe de normas independentes, pois, faz parte da base originária do sistema jurídico e não se altera mesmo quando haja dinamismo dentro dele. Por outras palavras, as normas independentes formam a base do primeiro sistema jurídico (sistema "originário") que dá início a uma ordem jurídica comum. As normas independentes, assim, formam o conjunto finito do qual se extraem as infinitas conseqüências lógicas compreendidas por uma ordem jurídica. Daí, como todas as normas "dependentes" contidas numa mesma ordem jurídica decorrem, em última análise, de tais normas "independentes", é possível dizer que são estas que identificam o sistema jurídico tanto no sentido estático/sincrônico quanto no sentido dinâmico/diacrônico.

${ }^{24}$ GUASTINI, Teoria..., p. 131.

${ }^{25}$ Cf. BULYGIN, Eugenio. El problema de la validez en Kelsen. In: KELSEN, Hans; BULYGIN, Eugenio; WALTER, Robert. Validez y eficacia del derecho. Buenos Aires: Editorial Astrea, 2005, p. 113.

${ }^{26}$ Para NEVES, "pertencem ao sistema jurídico todas as normas que possam retrotrair imediata ou mediatamente ao núcleo normativo que estabelece os órgãos e/ou fatos básicos da produção jurídica." (NEVES, Marcelo. Teoria da inconstitucionalidade das leis. São Paulo: Saraiva, 1988, p. 43.) 27 Segundo BULYGIN e MENDONCA (Normas y sistemas..., p. 47), é logicamente possível conceber fórmulas que combinem ambos os critérios, mas a conjunção dos critérios da dedutibilidade com o da legalidade é o que melhor explica e reconstrói os fatores de pertinência sistêmica no direito.

${ }^{28}$ Ver BULYGIN, Algunas consideraciones..., p. 265.

Revista Publicum

Rio de Janeiro, v. 3, n. 1, 2017, p. 307-351.

http://www.e-publicacoes.uerj.br/index.php/publicum

DOI: 10.12957/publicum.2017.29464 


\section{Validade das normas jurídicas}

Na filosofia jurídica, não há consenso sobre a definição de validade das normas jurídicas ${ }^{29}$. Para os jusnaturalistas, a validade tem a ver com certas concepções valorativas que serviriam de fundamentos suprapositivos às normas jurídicas. Nessa linha, a validade normativa dependeria da conformidade que as normas mantivessem, por exemplo, com a vontade divina ou com postulados racionais emanados da "natureza humana". É problema, pois, de conteúdo valorativo.

Já para os adeptos do realismo jurídico, a validade das normas varia de acordo com a aceitação social que possuam ou com a aplicação que lhes vem sendo dada por determinadas autoridades. Problema, portanto, de eficácia social ou do grau de obediência que possam desfrutar na sociedade.

Porém, para os positivistas de inspiração kelseniana, a validade confunde-se com a noção de existência/pertinência. Problema, pois, puramente de adequação normativa. Para que uma norma seja considerada válida, pode ser suficiente tenha sido produzida conforme processos autorizados por normas consideradas superiores a ela. Nesse sentido, como KELSEN nunca aceitara que num ordenamento jurídico existissem normas não válidas, a validade normativa, para ele, acabava por confundir-se com a própria existência da norma. De modo que não poderia "existir" uma norma "não válida"30.

Atualmente, contudo, a maior parte da doutrina concorda em que uma norma jurídica, para ser considerada válida, deverá estar de acordo com todas as metanormas

${ }^{29}$ Bom resumo acerca do assunto encontra-se em FLORES MENDOZA, Imer Benjamín. La concepción del derecho en las corrientes de la filosofía jurídica. Boletín Mexicano de Derecho Comparado, Cidade do México, n. 90, p. 1001-1036, set./dez. 1997. Disponível em: <http://www.juridicas.unam.mx/publica/librev/rev/boletin/cont/90/art/art6.pdf>. Acesso em: 28 mar. 2004.

${ }^{30}$ E foi por causa dessa confusão que KELSEN teve de explicar a relação de "validade" até da primeira constituição de um ordenamento jurídico - o que ele fez mediante a utilização de uma norma fundamental "pressuposta" -, quando era suficiente dizer que que a primeira constituição não precisa ser válida, pois suficiente que "exista" como tal. Quanto à necessidade de justificar a validade das normas soberanas (ou independentes) do sistema jurídico, a escola kelseniana é bastante criticada, seja pela teoria "descritiva" (ver, sobretudo, HART, O conceito de direito. 3. ed. Trad. A. Ribeiro Mendes. Lisboa: Fundação Calouste Gulbenkian, 2001), seja pela teoria "definitória", defendida por BULYGIN e MENDONCA (op. cit.), além de GUASTINI e vários outros. Nessa última linha, parece correta a lição de GUASTINI, para quem as "normas que conferem poderes normativos são mencionadas nos critérios de validez e de pertinência de um ordenamento, porém não são elas mesmas critérios de validez ou de pertinência. (...) As normas da constituição (ou da "primeira» constituição, se se prefere) são normas existentes no ordenamento, pertencentes a ele, e sem embargo não-válidas: mais precisamente, nem válidas nem inválidas, é dizer, "soberanas», «independentes»." (GUASTINI, Riccardo. Normas supremas. Doxa. Cuadernos de Filosofía del Derecho, Alicante, n. 17-18, p. 257-270, 1995.)

Revista Publicum

Rio de Janeiro, v. 3, n. 1, 2017, p. 307-351.

http://www.e-publicacoes.uerj.br/index.php/publicum

DOI: $10.12957 /$ publicum.2017.29464 
que disciplinam o respectivo processo de produção (validez formal), além de manter-se na linha de consistência lógica derivada das normas superiores pertencentes ao mesmo sistema jurídico (validez material). ${ }^{31}$ Prevalece a ideia de que a questão da validade normativa se relaciona com a conformidade estrita da norma ante todas as metanormas e normas que the sejam superiores e que pertençam ao mesmo sistema jurídico considerado. Daí a necessidade de não confundir a questão da validade com a questão paralela da existência normativa ${ }^{32}$.

As diferenças entre validade e existência normativa giram em torno, principalmente, da constatação de que a existência/pertinência de uma norma depende apenas da observância de algumas das metanormas que regulam a competência para promulgá-la. Ou seja, diferentemente da noção de validade normativa, não é condição necessária à existência de uma norma a eventual compatibilidade que esta deva manter com o conteúdo de normas superiores a ela ${ }^{33}$. Como explica GUASTINI ${ }^{34}$ :

(1.1). Grosso modo (deixando de lado, para simplificar, os critérios de validez das implícitas, que mencionei acima), em sistemas jurídicos contemporâneos, ou na maior parte deles, chama-se válida toda norma que: (a) tenha sido formalmente produzida de acordo com as regras sobre a produção do direito - ou meta-regras - que regulam sua produção (validade formal), e (b) não seja materialmente desconforme às normas hierarquicamente superiores que limitam seu possível conteúdo (validade material).

(1.2.) diferentemente, atribui-se pertinência a um ordenamento, ou existência, a toda norma que: (a) mesmo na ausência de validade substantiva, esteja, ao menos prima facie, dotada de validez formal (haja sido produzida por uma autoridade competente em conformidade com pelo menos algumas das regras procedimentais que regulam a produção normativa), ou bem (b), mesmo na ausência de validez formal, haja adquirido vigência, isto é, seja geralmente aceitada e observada pelos seus destinatários (princípio da eficácia).

Em consequência, nem toda norma pertencente a um ordenamento é também válida nele.

\footnotetext{
${ }^{31}$ Nessa linha, por todos, cf. GUASTINI, Teoria..., p. 129 e segs.

32 Como ensina MARCELO NEVES, "ao passo que nos sistemas normativos estáticos, onde as normas são explicitadas mediante processos de derivação lógico-dedutiva desenvolvidos a partir da norma básica, a pertinência da norma implica a sua validade interna e vice-versa, os sistemas jurídicos, construídos e desenvolvidos através de processos políticos e técnicos de produção-aplicação normativa, caracterizam-se por uma nítida distinção entre pertinência e validade das normas." (Op. cit., p. 41.)

33 GUASTINI, Teoria..., p. 131.

${ }^{34}$ GUASTINI, Normas supremas..., cit.
}

Revista Publicum

Rio de Janeiro, v. 3, n. 1, 2017, p. 307-351.

http://www.e-publicacoes.uerj.br/index.php/publicum

DOI: 10.12957/publicum.2017.29464 


\section{Inconstitucionalidade: caso de inexistência ou invalidade?}

A inconstitucionalidade, em sentido amplo, é o nome dado a qualquer relação de incompatibilidade $^{35}$ verificada na comparação entre algum comportamento ${ }^{36}$ e pelo menos uma das normas consideradas integrantes do "bloco de constitucionalidade" ${ }^{37}$. Já num conceito estrito, a inconstitucionalidade fica resumida às relações de desconformidade direta e atual com o bloco de constitucionalidade, desde que manifestadas em atos provenientes do Poder Público.

No caso específico das normas jurídicas, não importa se adotado o conceito amplo ou o restrito, a inconstitucionalidade é resultado da verificação de um tipo específico de conflito normativo a envolver, de um lado, os padrões normativos que integram o bloco de constitucionalidade e, de outro, uma norma hierarquicamente subordinada a eles ${ }^{38}$. Nessa linha, a inconstitucionalidade é espécie de antinomia que envolve necessariamente a ideia de supremacia constitucional e que, uma vez reconhecida, significa ou a inexistência/impertinência ou a invalidade da norma reputada inconstitucional.

De fato. A circunstância de o ato ser inexistente não impede seja também considerado inconstitucional. Basta que a inexistência derive da própria relação de inconstitucionalidade, ou seja, que os pressupostos mínimos de existência jurídica definidos para aquele tipo de norma sejam fixados ou extraídos diretamente da própria constituição. (No Brasil, por exemplo, se um funcionário da Imprensa Nacional fizer publicar no Diário Oficial da União um ato com a aparência de lei, mas que não tenha sido

35 Nesse sentido amplo, a verificação de uma inconstitucionalidade não leva em consideração somente as configurações momentâneas de um dado sistema jurídico, nem discrimina os critérios (cronológico, hierárquico ou da especialidade) que se devam considerar descumpridos, tampouco a natureza direta ou indireta da desconformidade.

${ }^{36}$ Logo, embora a doutrina quase sempre se refira somente à inconstitucionalidade de atos normativos, tanto a omissão do Poder Público quanto até mesmo atitudes de particulares podem representar inconstitucionalidades. Nesse sentido: MIRANDA. Jorge. Contributo para uma teoria da inconstitucionalidade. Reimpr. Coimbra: Coimbra Ed., 1996, p. 11; e ZAVASCKI, Teori Albino. Eficácia das sentenças na jurisdição constitucional. São Paulo: RT, 2001, p. 13-14.

${ }^{37}$ A expressão "bloco de constitucionalidade" teve origem no direito constitucional francês do início da década de 1970, mais exatamente 1974, no estudo feito por FAVOREU em homenagem a EISENMANN. Segundo o próprio FAVOREU, foi a partir da noção de "bloco de legalidade", desenvolvida por MAURICE HAURIOU, que nasceu a concepção de "bloco de constitucionalidade", utilizada para designar o conjunto de princípios e regras de valor constitucional. Diz ele ainda que se alude ao termo "bloco" para ilustrar a ideia de solidez e unidade (cf. FAVOREU, Louis; RUBIO LLORENTE, Francisco. El bloque de la constitucionalidad. Madrid: Civitas, 1991, p. 19-21 e 58-59).

38 Nos ordenamentos que estabelecem limitações ao poder de reforma constitucional, podem ser consideradas inconstitucionais não só as normas infraconstitucionais como também as normas decorrentes de emenda constitucional e até mesmo as provenientes de mutação, convenção ou costumes constitucionais. Todavia, no caso das emendas constitucionais, os padrões integrantes do bloco de constitucionalidade que podem ser invocados para se considerá-las inconstitucionais fica reduzido só às normas que, explícita ou implicitamente, imponham limites ao exercício do poder constituinte derivado. 
alvo de qualquer deliberação ou promulgação legislativas, esse ato será inexistente e ao mesmo tempo inconstitucional, pois é diretamente da Constituição Federal que se extraem as metanormas a respeito da competência para promulgar leis. ${ }^{39}$ )

De outro lado, um órgão estatal, embora competente para editar certo tipo de normas, poderá promulgá-las sem observar totalmente, seja a disciplina constitucional que rege o respectivo processo de produção, seja o conteúdo que thes é imposto pelo bloco de constitucionalidade. Nesses casos, as normas pertencerão ao ordenamento jurídico, mas apresentarão defeitos quanto à validade. Essas normas, portanto, embora existentes/pertinentes, padecerão de inconstitucionalidade, a qual, no caso, irá confundirse com a noção de invalidade.

Daí que, nada obstante as eventuais dificuldades para separar os pressupostos de existência dos de validade dos atos normativos; e mesmo nos sistemas jurídicos que não se preocuparam em definir tais diferenças (caso do sistema brasileiro); descabe confundir os conceitos de inexistência e invalidade.

Entre outras coisas, depende dessa distinção, v.g., a própria extensão do controle de constitucionalidade. Basta notar que, inclusive nos países cuja constituição é flexível, quaisquer juízes têm competência para recusar aplicação a atos normativos inexistentes, embora não a tenham quando o vício da inconstitucionalidade se resumir à invalidade ${ }^{40}$. Ademais, até nos sistemas que só adotam o controle concentrado de constitucionalidade,

39 Caso paradigmático de inexistência de ato normativo parece ser aquele relativo ao parágrafo único do art. 11 da Lei 9.639 , de 25-5-98 (publicada no $D O U$ de 26-5-98 e originária da conversão da MP 1.608-14, de 28-4-98). Tal dispositivo pretendia estender anistia penal a particulares que se haviam apropriado, indevidamente, de contribuições sociais destinadas ao Instituto Nacional do Seguro Social - INSS. Contudo, por incrível que pareça, referido parágrafo foi inserido na publicação da aludida lei sem que tivesse ultrapassado qualquer fase do respectivo processo legislativo. Então, retificando esse erro, foi republicada a Lei $9.639 / 98$ no dia seguinte (DOU de 27-5-98). Todavia, o fato de se considerar o parágrafo único do art. 11 da Lei 9.639/98 um ato inexistente não impediu que o Plenário do STF o reputasse inconstitucional no julgamento do HC 77.734/SC (Rel. Min. NÉRI DA SILVEIRA, DJU de 10-8-2000, p. 05) e do HC 77.724/SP (Rel. Min. MARCO AURÉLIO, DJU de $02 / 02 / 2001$, p. 74). Nesse sentido, atribuindo expressamente a pecha de inexistente àquele dispositivo, veja-se, em especial, o seguinte trecho do voto do Min. MARCO AURÉLIO no HC 77.724/SP: "Ora esse dispositivo [\$4을 do art. 10 da LICC] é de molde a sanear defeito como o presente, ligado à inobservância do processo legislativo no que tem de essencial, que é a manifestação de vontade dos representantes do povo e dos representantes do Senado? Tal norma é capaz de validar o nada, o inexistente, como ressaltado em parecer emitido na câmara própria do Ministério Público Federal, pelo Professor Cláudio de Lemos Fontelles? A resposta é desenganadamente negativa.".

40 Cf. GUASTINI, Riccardo. Estudios de teoría constitucional. (Col. Doctrina Jurídica Contemporánea). Trad. Maria Bono, Perfecto Andrés, José Maria Lujambio, Andréa Greppi e Miguel Cargonell. México: Miguel Cargonell, 2001, p. 91. Disponível em: <http://www.bibliojuridica.org/libros/libro.htm?l=22>. Acesso em: 5 jun. 2002. O que se pretende aclarar é que a inexistência pode decorrer de relação de inconstitucionalidade e que ninguém - os juízes muito menos - deve obediência aos atos cuja inexistência seja determinada pelo descumprimento de normas constitucionais, até mesmo num regime ditado por constituição flexível.

Revista Publicum

Rio de Janeiro, v. 3, n. 1, 2017, p. 307-351.

http://www.e-publicacoes.uerj.br/index.php/publicum

DOI: 10.12957/publicum.2017.29464 
tampouco será preciso suscitar incidente de inconstitucionalidade para declarar-se inexistente algum ato. Ou seja, ainda que esse incidente processual se exija para reconhecer a invalidade constitucional do ato, não é sequer necessário para que se reconheça a inexistência dele ${ }^{41}$. Além disso, embora alguns ordenamentos jurídicos como o brasileiro - admitam fixar efeitos ex nunc ou pro futuro à declaração de inconstitucionalidade, trata-se de modalidade de convalidação parcial do ato inconstitucional que só deveria ser aplicada para consolidar efeitos de atos inválidos, e não dos que nunca chegaram a existir ${ }^{42}$.

Enfim, os conceitos de existência, de validade e de constitucionalidade normativas têm a ver com relações de conformidade entre a norma examinada e determinadas normas (e metanormas) que lhe sejam "superiores" ${ }^{43}$. Logo, a invalidade ou a inexistência configurará também algum tipo de inconstitucionalidade sempre que a norma superior contrariada fizer parte do repertório de normas extraído diretamente do bloco de constitucionalidade. Daí a explicação por que a inconstitucionalidade de uma norma significa necessariamente que esta padece ou de inexistência ou de invalidade ${ }^{44}$.

\section{Existência/pertinência e validade vs. aplicabilidade}

\section{normativas}

Em perspectiva dinâmica, o sistema jurídico ("ordem jurídica" ou “ordenamento jurídico"), com se viu, abrange todas as normas pertencentes a cada uma das diversas configurações

${ }^{41}$ Cf. SOUSA, Marcelo Rebelo de. O valor jurídico do acto inconstitucional. Lisboa: [s.n.], 1988, p. 183.

42 Nesse sentido, OTERO, Paulo Manuel Cunha da Costa. Ensaio sobre o caso julgado inconstitucional. Lisboa: Lex, 1993, p. 64-65. Em sentido parcialmente contrário, afirma MEDEIROS, "se é indiscutível que a gravidade do vício subjacente às hipóteses da chamada inexistência da lei dificilmente se compadece com uma limitação dos efeitos da inconstitucionalidade - e a conclusão impõe-se, por maioria de razão, quando se acrescenta a exigência da evidência do vício -, não é menos verdade que, em situações-limite, a salvaguarda de outros interesses constitucionais igualmente fundamentais pode, em face das circunstâncias concretas do caso, impor uma restrição dos efeitos da declaração de inexistência." (MEDEIROS, Rui. A decisão de inconstitucionalidade: os autores, o conteúdo e os efeitos da decisão de inconstitucionalidade da lei. Lisboa: Universidade Católica, 1999, p. 876.)

${ }^{43}$ Não vem ao caso saber se tais normas "superiores" derivam, em última instância, de outra norma (de direito positivo ou não), ou mesmo que hipotética (KELSEN), ou se de uma "regra de reconhecimento" atrelada a circunstâncias ligadas à identificação do direito existente (HART).

44 Neste ponto, a exposição acima se desvencilha inteiramente da teoria de KELSEN. Para quem segue a doutrina kelseniana, a afirmação de que uma lei válida é contrária à constituição é uma contradictio in adjecto, já que uma lei somente pode ser válida se encontrar fundamento na constituição. Para KELSEN, uma lei inválida nunca pode ser considerada contrária à constituição, já que não é sequer uma lei, mas algo juridicamente inexistente, sobre o qual não se pode então fazer qualquer afirmação jurídica.

Revista Publicum

Rio de Janeiro, v. 3, n. 1, 2017, p. 307-351.

http://www.e-publicacoes.uerj.br/index.php/publicum

DOI: 10.12957/publicum.2017.29464 
momentâneas do mesmo sistema. Nessa visão das coisas - que em parte coincide com o chamado "direito histórico" -, uma norma não deixa de existir por ter sido revogada ou substituída por outra, tampouco por haver sido declarada inválida, ainda que por decisão dotada de efeitos gerais (erga omnes).

Todavia, a se considerar um sistema jurídico sob a perspectiva momentânea, os atos de promulgação de novas normas no momento $T$, sempre que implicarem a revogação de normas existentes, importarão, no momento seguinte $\left(T^{\prime}\right)$, na eliminação da pertinência das normas revogadas em face daquele sistema. Nessa perspectiva sincrônica, o conceito de existência/pertinência aproxima-se do de vigência, já que só se mantêm pertencentes ao sistema jurídico as normas que não tenham sido revogadas. Ademais, pela mesma perspectiva, idêntico fenômeno de perda da pertinência ocorrerá quando uma norma, embora existente, for posteriormente expulsa do sistema jurídico em razão de invalidade, tal como decorre da declaração de inconstitucionalidade com efeitos gerais (erga omnes) ${ }^{45}$.

Essa constatação é bastante importante para compreender o dinamismo que caracteriza as ordens jurídicas. Até porque, como explica BULYGIN, "as normas que um juiz aplica a um caso num determinado momento não necessariamente têm que pertencer ao sistema correspondente a esse momento." 46

Com efeito, é comum e absolutamente regular aplicação de certas normas que não pertencem mais à configuração momentânea do sistema jurídico. Ou seja, ainda que uma norma já não pertença mais a um sistema jurídico sincrônico, por ter sido revogada ou expulsa desse sistema, e mesmo uma norma que nem sequer tenha pertencido a uma dada ordem jurídica - v.g., as normas de direito internacional não internalizadas pelo

\footnotetext{
${ }^{45}$ Nos casos de comprometimento da eficácia de uma norma, esta só será considerada expulsa do sistema jurídico - portanto, não mais existente - se a perda da eficácia ocorrer de maneira definitiva. (Nesse sentido, MARCELO NEVES, op. cit., p. 52.) No Brasil, hipótese de expulsão desse tipo seria aquela proveniente da suspensão da execução de norma por resolução do Senado Federal editada nos termos do inciso $X$ do art. 52 da Constituição (NEVES, idem). Contudo, embora a jurisprudência do STF já tenha entendido que a resolução do Senado é irrevogável (RTJ 38:23) - o que vai ao encontro da tese da definitiva expulsão da norma cuja execução é suspensa - melhor pensar como SÉRGIO RESENDE DE BARROS, segundo o qual, se "para editar a resolução a competência do Senado é discricionária, para revogá-la é vinculada, pois, se o Supremo reconsiderar a inconstitucionalidade e, mesmo assim, o Senado mantiver a resolução, este estará usurpando a competência daquele e, também, a do Congresso Nacional, uma vez que a lei feita pelo Legislativo e considerada constitucional pelo Judiciário tem de ter vigência plena e ser plenamente aplicável. Portanto, o retorno não é só possível, mas pode vir a ser necessário, e não há por que negá-lo." (BARROS, Sérgio Resende de. Constituição, artigo 52, inciso X : reversibilidade? Revista de Informação Legislativa, Brasília, n. 158, abr./jun. 2003, p. 236.) Daí, em sendo reversível a perda de eficácia da norma cuja execução tenha sido suspensa pelo Senado, não se trata de verdadeira hipótese de expulsão ou de perda de pertinência. A norma permanece no sistema jurídico, embora não possa mais, indefinidamente, ser aplicada ou surtir consequências jurídicas.

${ }^{46}$ Algunas consideraciones..., p. 267.
}

Revista Publicum

Rio de Janeiro, v. 3, n. 1, 2017, p. 307-351.

http://www.e-publicacoes.uerj.br/index.php/publicum

DOI: 10.12957/publicum.2017.29464 
direito estatal - poderão ser regularmente aplicadas naquele sistema jurídico ao qual deixaram de pertencer ou ao qual nunca chegaram pertencer.

Portanto, a aplicabilidade de uma norma depende é da pertinência momentânea das metanormas que fixam critérios de aplicação das normas jurídicas, e não dos critérios que regulam a pertinência ou a validade (incluindo a constitucionalidade) da norma em face do sistema jurídico em cujo âmbito deva ser aplicada. Nas palavras de BULYGIN:

Do que foi dito se depreende que as normas que um juiz aplica a um caso num determinado momento não necessariamente têm que pertencer ao sistema correspondente a esse momento. De fato, as normas que os juízes aplicam para resolver um caso, frequentemente, pertencem a sistemas diferentes da mesma ordem jurídica e, à vezes, pode tratar-se de normas pertencentes a outras ordens jurídicas. (Existe toda uma disciplina jurídica Direito Internacional Privado - que estuda os casos em que a aplicação procede do direito estrangeiro.) $O$ que o juiz faz efetivamente é determinar seguindo os critérios de aplicabilidade - que normas são aplicáveis ao caso e logo constrói um sistema à base dessas normas, que com frequência são uma seleção de sistemas que correspondem a diferentes momentos temporais. Existe, sem embargo, um sentido em que cabe dizer que o sistema correspondente ao momento em que o juiz há de tomar sua decisão é efetivamente um sistema privilegiado: os critérios de aplicabilidade das normas que o juiz usa têm que pertencer a esse sistema. Em outras palavras, o juiz deve usar os critérios de aplicabilidade vigentes, se bem que esses critérios de aplicabilidade podem remetê-lo a normas pertencentes a sistemas anteriores, já derrogadas, e inclusive a normas pertencentes a outras ordens jurídicas (cfr., Bulygin, 1982). ${ }^{47}$

E os exemplos desse fenômeno são vários. No direito brasileiro, basta lembrar os seguintes: (a) a metanorma do inciso XL do art. 5 da Constituição impõe a aplicação da norma penal revogada, se mais favorável que a norma revogadora; (b) a metanorma do inciso XXXVI do art. 5o da Constituição determina a aplicação da lei revogada em detrimento daquela que estabelecer nova disciplina jurídica quanto a um direito já adquirido; (c) a metanorma do $\S 11$ do art. 62 da Constituição determina a aplicação de medida provisória rejeitada com efeitos retroativos pelo Congresso Nacional, caso este não venha a editar decreto legislativo em sentido contrário no prazo de 60 dias; (d) o STF, com base em metanormas constitucionais implícitas (princípios da boa-fé e da segurança jurídica), já admitiu a aplicação de norma anteriormente expulsa do sistema por motivo de inconstitucionalidade declarada, por ele próprio, com efeitos erga omnes ${ }^{48}$; (e) as

47 Idem.

48 RE 442.683/RS, 2a Turma, rel. Min. CARLOS VELLOSO, DJU de 24-3-2006. O caso versava sobre ação civil pública movida para desconstituir ato de Tribunal Regional do Trabalho pelo qual se concedera, sem concurso público, ascensão funcional a servidores públicos federais, após a Constituição de 1988. Todavia, embora o STF já tivesse decidido inúmeras vezes que tal tipo de acesso a cargo público violava a Constituição Federal e houvesse até declarado inconstitucionais na 
metanormas constantes dos artigos 7ํa a 10 da Lei de Introdução às Normas do Direito Brasileiro $^{49}$ impõem a aplicação de normas estrangeiras em diversas situações.

E idêntico fenômeno ocorre não somente na aplicação de normas inconstitucionais, enquanto não tenham sido assim declaradas, como também na aplicação de normas inconstitucionais que hajam sido indevidamente declaradas constitucionais. Como explica BULYGIN ${ }^{50}$ :

Agora bem, a constitucionalidade de uma lei não depende de que o diga o Tribunal Constitucional e uma lei que não foi ditada por uma autoridade competente segue sendo inconstitucional, mesmo que o Tribunal diga o contrário. Porém, é o pronunciamento do Tribunal Constitucional que determina a aplicabilidade da lei. Se o Tribunal disse (erroneamente) que a lei é constitucional, a lei será aplicável, ainda que não seja válida no sistema. Esta tese, que pode parecer chocante a muitos juristas, é, sem embargo, mera conseqüência lógica da definição de pertinência das normas ao sistema ou validez no sistema. Uma norma pertence a um sistema ou é válida nele, se, e somente se, foi criada pela autoridade competente e não quando alguém diga que tenha sido criada pela autoridade competente, mesmo que esse «alguém» seja o tribunal de última instância, competente para decidir acerca da constitucionalidade das leis.

Esse último caso, aliás, é bastante interessante ao presente estudo. Afinal, evidencia que a aplicação de uma norma inconstitucional pode ser obrigatória por força da metanorma que assegura estabilidade até à decisão judicial que a declarara constitucional por equívoco. E quando essa decisão é dotada de efeitos erga omnes, sucede a própria convalidação judicial da norma inconstitucional, que se mantém pertinente mesmo sendo inválida, tudo em virtude da imodificabilidade e da eficácia geral da decisão do tribunal que, erroneamente, a tenha declarado constitucional ${ }^{51}$.

ADIn 837/DF os dispositivos da Lei $8.112 / 90$ nos quais se embasara o ato atacado, o Supremo resolveu manter acórdão do TRF/4a Região que atribuíra efeitos meramente ex nunc, no caso concreto, à declaração de inconstitucionalidade dos mesmos artigos declarados inconstitucionais, com eficácia ex tunc, na ADIn 837/DF.

49 Nova denominação da antiga Lei de Introdução ao Código Civil (Decreto-Lei 4.657, de 4-9-42).

${ }^{50}$ Algunas consideraciones..., p. 267.

51 Em sentido similar, para GUASTINI, nos ordenamentos jurídicos em que se admite conceder eficácia erga omnes à decisão declaratória da constitucionalidade abstrata de uma norma - o que ocorre no caso brasileiro, mas não no italiano -, a rejeição equivocada do pronunciamento da invalidade de uma norma constitucionalmente inválida implica a convalidação dessa invalidade, com a consequente inclusão das normas "convalidadas" na classe das normas existentes. Ver Teoria e dogmatica..., p. 150. 


\section{III - Decisões judiciais e sistemas jurídicos}

Regra geral, o poder jurisdicional do Estado é exercido por juízes para resolver questões de fato e/ou de direito em torno das quais gravitam conflitos intersubjetivos ${ }^{52}$. Nessa tarefa, são emitidas decisões judiciais cujo escopo não é propriamente eliminar tais conflitos, mas impedir que eles se propaguem ou se perpetuem, com o objetivo último de absorção da insegurança ${ }^{53}$.

\section{Juízes "criam" direito?}

Examinados os critérios de identificação e de introdução de elementos normativos a um sistema jurídico, é preciso analisar se as decisões judiciais podem também ser consideradas fontes autorizadas de produção normativa.

Acerca da questão, BULYGIN alinhou três teorias: (a) a teoria tradicional, a sustentar que o sistema jurídico é constituído somente pelo conjunto de normas gerais criadas pelo legislador, competindo aos juízes apenas "aplicar" o direito a casos particulares; (b) a teoria kelseniana, segundo a qual o sistema jurídico engloba tanto as normas gerais quanto as particulares, daí por que, quando os juízes proferem decisões relativas a casos concretos, estão a "criar" normas jurídicas particulares; e (c) a teoria intermediária, conforme a qual, embora as normas particulares estabelecidas em sentenças judiciais normalmente não configurem criação de normas, senão mera "aplicação" do direito, os juízes criam normas jurídicas, em situações especiais, quando obrigados a fundamentar suas decisões com base em premissas normativas (normas gerais) que até então não existiam no sistema ${ }^{54}$.

Segundo a teoria tradicional, o sistema jurídico, propriamente dito, abrange somente normas gerais. Porém, mesmo quando as leis são incompletas, o direito não o é. Isso porque, a despeito das omissões eventualmente contidas na lei, o juiz dispõe de outros mecanismos, que também fazem parte do direito (princípios, analogia, costumes, equidade), para resolver todos os casos concretos. Logo, os juízes não criam direito, senão se limitam a aplicar ou normas gerais ou mecanismos jurídicos que os permitem identificar as soluções sistêmicas para qualquer situação fática.

52 Essa explicação, obviamente, não tenta alcançar o exercício jurisdicional que ocorre em "processos objetivos", nos quais inexistem conflitos intersubjetivos de interesse.

53 Ver FERRAZ JR., Tercio Sampaio. Introdução ao estudo do direito: técnica, decisão, dominação. 3. ed. São Paulo: Atlas, 2001, p. 308-309.

${ }^{54}$ BULYGIN, Eugenio. Los jueces ¿crean derecho? Isonomia. Revista de Teoría e Filosofía del Derecho. Instituto Tecnológico Autónomo de México. n. 18, abr. 2003, p. 7. 
Todavia, essa teoria é insatisfatória, pois renega o trabalho criativo dos juízes quando, por exemplo, integram lacunas jurídicas. Sustenta que a presença de mecanismos jurídicos para resolver o problema significa que os juízes não criam a norma para o caso, mas esquece de que, da circunstância de ser possível aos juízes integrar lacunas, não se extrai a conclusão segundo a qual elas não tenham existido.

A segunda teoria, cujo mais conhecido precursor é KELSEN, parte do raciocínio de que o direito não é só constituído de normas gerais, mas também de normas particulares ${ }^{55}$. Assim, além das normas gerais criadas pelo legislador lato sensu, os atos dos aplicadores do direito que visam a individualizá-las, especialmente as sentenças judiciais, também criam direito. Daí, a criação do direito não se resume na promulgação de normas gerais, pois inclusive as normas particulares - tais quais as criadas pelas sentenças judiciais - fazem parte de um processo de produção normativa, criativo e dinâmico, de individualização crescente, a partir da norma fundamental. A função dos tribunais não é somente a "descoberta" do direito, num sentido meramente declaratório de "juris-dição". Descobrir o direito é simplesmente identificar a norma geral aplicável, e o tribunal deve ainda decidir outras questões - como a verificação da situação fática necessária à incidência da norma geral ou a análise da constitucionalidade dessa norma antes de decidir pela aplicação, in concreto, da previsão estabelecida in abstracto. Assim, a sentença individual é que completa o comando normativo geral estabelecido no ordenamento jurídico ${ }^{56}$.

Entretanto, a despeito de ainda contar com muitos adeptos, há na tese kelseniana uma sobrevalorização da atividade judicial de concretização e acomodação das normas gerais a casos particulares. O próprio KELSEN diferenciou situações em que, diversamente da simples concretização de normas gerais, o juiz cria normas jurídicas - que não estão, de nenhuma forma, predeterminadas numa norma jurídica geral positiva - em face daquelas outras situações nas quais a norma individual é criada pelo tribunal, a partir da predeterminação contida numa norma geral ${ }^{57}$. E, como KELSEN mesmo admitiu, é muito diferente a sentença proferida em concretização do que predeterminam normas gerais, se

55 Disse KELSEN: “Tendo identificado 'lei' e 'regras', podemos, é claro, reconhecer como Direito apenas as normas gerais. Mas não há dúvida de que o Direito não consiste apenas em normas gerais. O Direito inclui normas individuais, i.e., normas que determinam a conduta de um indivíduo em uma situação irrepetível e que, portanto, são válidas apenas para um caso particular e podem ser aplicadas apenas uma vez. Tais normas são 'Direito' porque são partes de uma ordem jurídica como um todo, exatamente no mesmo sentido das normas gerais com base nas quais elas foram criadas. Exemplos de tais normas particulares são as decisões dos tribunais, nna medida em que sua força de obrigatoriedade seja limitada ao caso particular em questão." (KELSEN, Hans. Teoria geral do direito e do estado. 2. ed. Trad. Luís Carlos Borges. São Paulo: Martins Fontes, 1992, p. 42.)

${ }^{56}$ Cf. KELSEN, Teoria pura..., p. 327 e segs.

${ }^{57}$ Cf. KELSEN, Teoria pura..., p. 337.

Revista Publicum

Rio de Janeiro, v. 3, n. 1, 2017, p. 307-351.

http://www.e-publicacoes.uerj.br/index.php/publicum

DOI: 10.12957/publicum.2017.29464 
comparada com outras situações nas quais o juiz decide sem que haja nenhuma predeterminação estabelecida em norma de caráter geral. Daí, embora não existam dúvidas quanto à importância do trabalho de concretização das normas gerais por parte do aplicador do direito, é plenamente possível diferenciar atividades que se constituem em autêntica "criação" normativa daquelas em que o ocorre é a simples "aplicação" de normas pré-constituídas.

Como anota GUASTINI, a formulação de uma norma só é verdadeiramente "criação normativa" se ela já não estivesse logicamente implícita noutra norma preexistente ${ }^{58}$. Mesmo que se concorde em que o juiz, e somente ele, é o autor da norma individual contida na sentença, "esta norma individual não pode ser considerada 'nova' (criada ex novo) num sentido importante: no sentido de que essa norma era já logicamente implícita na norma geral que o juiz há dado aplicação. ${ }^{59 "}$ Portanto, a atuação judicial, via de regra, não é efetiva fonte produtora de novas normas, pois a tarefa da jurisdição é basicamente a de "revelar" normas preexistentes, ainda que implicitamente, a partir do conjunto das normas utilizado como parâmetro para o julgamento ${ }^{60}$. E como o Judiciário tem de motivar seus pronunciamentos, o princípio da separação entre as funções estatais torna obrigatória a demonstração argumentativa de que a norma aplicada pela sentença já preexistia, mesmo que em estado de latência, no ordenamento jurídico considerado ${ }^{61}$.

$\mathrm{Na}$ mesma linha, conforme teoria intermediária de BULYGIN, embora correta a ideia de que a parte dispositiva da sentença é ato de vontade, bem como a de que o juiz, ao decidir, agrega uma série de dados que não figuram na norma geral, nada disso significa que o juiz cria novas normas quando decide casos concretos. Só se pode falar em autêntica produção normativa, pela via judicial, quando a norma geral, com base na qual o juiz fundamenta e justifica sua decisão, já não existisse, implícita ou explicitamente ${ }^{62}$; ou seja, somente quando o órgão judicial, no processo decisório, formula uma norma geral que não pode ser explícita nem implicitamente deduzida de normas preexistentes e, então, aplica essa norma ao caso concreto.

Aí está a grande distinção entre a teoria tradicional e a teoria intermediária. Enquanto e primeira defende que os juízes nunca criam direito novo, a outra sustenta

\footnotetext{
58 GUASTINI, Riccardo. Teoria e dogmatica delle fonti. Milano: Giuffrè, 1998, p. 102. Como explica o mesmo autor: "Quando o juiz infere logicamente uma norma individual de uma norma geral, não parece apropriado dizer que ele 'cria' algo." (Idem.).

59 Idem.

60 Ibidem, p. 102-103.

61 Ibidem, p. 104.

62 BULYGIN, Eugenio. Los jueces ¿crean derecho? Isonomia. Revista de Teoría e Filosofía del Derecho. Instituto Tecnológico Autónomo de México. n. 18, p. 7-25, abr. 2003.
}

Revista Publicum

Rio de Janeiro, v. 3, n. 1, 2017, p. 307-351.

http://www.e-publicacoes.uerj.br/index.php/publicum

DOI: 10.12957/publicum.2017.29464 
que, em casos excepcionais, os juízes acabam por proferir sentenças baseadas em normas gerais por eles próprios criadas. Esses casos, segundo BULYGIN ${ }^{63}$, são basicamente dois: (a) quando o juiz integra lacunas normativas e lacunas axiológicas; e (b) quando o juiz elimina contradições entre normas, e o resultado dessa atividade implica a derrogação, ainda que parcial, de alguma norma ${ }^{64}$.

\section{Decisão judicial e "criação" das normas individuais}

Como visto no item anterior, se a teoria tradicional prega a ideia de que juízes nunca criam normas; e se há motivos para discordar da teoria kelseniana segundo a qual a atividade judicante sempre envolve a criação de normas; é em torno da teoria intermediária que passam a girar os esforços em caracterizar, como fonte produtora de normas, os comandos provenientes de decisões judiciais acerca de casos concretos.

Ocorre que os próprios adeptos da teoria intermediária, via de regra, sustentam que "o sistema jurídico (e, consequentemente, a ordem jurídica) há de ser reconstruído de tal maneira que sua base só inclua normas gerais, e não normas individuais, como, por exemplo, as sentenças judiciais. ${ }^{65 "}$ Além disso, embora indique hipóteses excepcionais de criação normativa decorrente de decisões judiciais, a teoria intermediária deixa implícito que o efeito criativo aí presente radica na norma geral estabelecida nos "fundamentos", e não no dispositivo da decisão. Assim, como as decisões judiciais geralmente implicam só comandos individuais/concretos, surge a questão de saber se podem ou não ser consideradas "normas", mesmo não sendo "gerais".

De fato, em linha de princípio, preceitos individuais e/ou concretos, ainda que promulgados por altas autoridades judiciais, não merecem ser catalogados nos repertórios normativos de um sistema jurídico, sobretudo porque se trata de comandos que não passam de simples recortes específicos do campo de atuação das normas gerais.

\footnotetext{
${ }^{63}$ Ver BULYGIN, Los jueces ¿crean derecho?..., cit.

${ }^{64}$ Embora se concorde com o primeiro caso, o segundo parece desconsiderar a circunstância de que, quando os juízes resolvem antinomias, tampouco "criam" novos elementos normativos ex propia fonte, pois a atividade que aí realizam também se pode resumir à simples aplicação de metanormas (elementos estruturais) que preexistem no mesmo sistema.

65 BULYGIN e MENDONCA, Normas y sistemas..., p. 48. Nas palavras de BULYGIN: "Em outras palavras, opino que o sistema jurídico (e, por consequência, a ordem jurídica) há de ser reconstruído de tal maneira que sua base só inclua normas gerais e não as normas individuais, como, por exemplo, as sentenças judiciais. A descrição completa do direito vigente em um momento dado não incluiria seguramente tais normas individuais; uma especificação completa das normas gerais vigentes em um momento requerido seria considerada, sem dúvida, como uma descrição satisfatória. Por estas razões considero conveniente limitar a base do sistema a normas gerais; as normas individuais formarão parte do sistema só a título de consequências lógicas em virtude do princípio de dedutibilidade." (Algunas..., p. 262.)
} 
Logo, no caso de decisões judiciais que se limitem a aplicar normas preexistentes, não chegam mesmo a criar normas, nem a modificar o sistema jurídico, ainda que nessa atividade de proferir comandos individuais/concretos possa até existir alguma discricionariedade (como quando o juiz procede à dosimetria da pena de um criminoso, por exemplo).

Todavia, como é possível haver decisões judiciais que determinem a produção de consequências jurídicas exorbitantes das previsões logicamente extraídas das normas preexistentes, pode-se dizer que nessas hipóteses, como expõe GUASTINI, “o juiz 'cria' uma norma individual quando pronuncia uma decisão arbitrária (não justificada). ${ }^{66 "} \mathrm{Em}$ tais casos, as decisões judiciais, não importa se de conteúdo individual e/ou concreto, deverão ser examinadas como "tentativas" de alteração dos elementos normativos do sistema jurídico.

Surge aqui outro problema. A conclusão que se extrai do parágrafo acima é a de que as sentenças judiciais, mesmo que elaboradas de acordo com o critério da legalidade, só inovam o sistema jurídico quando não se atêm ao critério da dedutibilidade lógica. Isto é, ainda que os juízes, pelo critério da legalidade, estejam autorizados pelo sistema jurídico a "promulgar" novas normas em situações excepcionais, esse processo de criação de normas jurídicas pressupõe ou a insuficiência ou a inobservância do critério da dedutibilidade lógica.

Por outras palavras, o caráter inovador das normas jurídicas instituídas em sentenças judiciais não depende só da observância do critério geral da legalidade, representado pelo poder jurisdicional concedido aos juízes para integrar lacunas ou resolver conflitos entre normas. Vai depender, ainda, da aplicação de uma norma que não reconduza ao critério da dedutibilidade lógica.

Enfim, quando obedecem a ambos os critérios de extração de normas pertencentes ao sistema jurídico (critérios da legalidade e da dedutibilidade lógica), os juízes nada criam ao emitir sentenças individuais. A criação normativa, pela via judicial, pressupõe a observância do critério da legalidade, mas exige o afastamento do critério da dedutibilidade lógica. Daí a relevância de maiores estudos sobre os efeitos normativos inerentes às decisões judiciais, sobretudo quanto ao fenômeno da coisa julgada.

\section{IV - Coisa julgada inconstitucional}

\section{Definições prévias}

${ }^{66}$ Teoria..., p. 102.

Revista Publicum

Rio de Janeiro, v. 3, n. 1, 2017, p. 307-351.

http://www.e-publicacoes.uerj.br/index.php/publicum

DOI: 10.12957/publicum.2017.29464 
Enquanto as decisões judiciais se sujeitarem a recursos ou a expedientes processuais que possam modificá-las ou lhes adiar a eficácia, o processo decisório está em curso. Portanto, não há falar-se, ainda, em coisa "julgada". A pertinência dessa expressão, assim flexionada no particípio passado, surge só após a decisão "transitar" ou "passar em julgado" - i.e., somente depois de ultrapassada a fase processual durante a qual é ainda possível alterar os termos da decisão ou adiar a eficácia do comando proveniente do que já fora decidido. Daí se denominar de "coisa julgada" ou "caso julgado" a decisão judicial contra a qual já não caibam mais recursos ( $\S 40$ do art. 60 da Lei de Introdução às normas do Direito Brasileiro), tampouco remessa necessária (Novo Código de Processo Civil, art. 496).

Por conseguinte, a decisão judicial atinge seu mais alto grau de eficácia quando esgotada toda a cadeia de expedientes processuais capazes de influir, no todo ou em parte, nos efeitos que o comando decisório esteja apto a produzir. Ou seja, a coisa julgada não é propriamente um "efeito" decisório, mas fenômeno jurídico que indica o grau máximo de eficácia de uma decisão judicial ${ }^{67}$. Uma vez passada em julgado, a decisão judicial, regra geral, não poderá mais ser alvo de modificação, pelo menos no âmbito da mesma relação processual ${ }^{68}$.

${ }^{67}$ Além da coisa julgada decorrente do trânsito em julgado de decisões jurisdicionais, é comum aludir-se, ainda, à coisa julgada administrativa, que equivale ao efeito preclusivo decorrente do esgotamento dos recursos previstos na esfera decisória administrativa, i.e., a "irretratabilidade do ato parente a própria Administração" (MEIRELLES, Hely Lopes. Direito administrativo brasileiro. 16. ed. atual. São Paulo: Revista dos Tribunais, 1990, p. 576). Todavia, não se trata de verdadeira coisa julgada, pois tampouco impede rediscussões da matéria na esfera judicial (Constituição, art. 5o, XXXV), o que subtrai interesse pelo assunto. Por isso mesmo, decidiu o STF, a "coisa julgada a que se refere o artigo 5으, XXXVI, da Carta Magna é, como conceitua o § 3ㅇ do artigo 6o da Lei de Introdução ao Código Civil, a decisão judicial de que já não caiba recurso, e não a denominada coisa julgada administrativa" (RE 144.996/SP, 1a Turma, rel. Min. MOREIRA ALVES, j. em 29-4-97, DJU de 12-9-97, p. 43.732).

${ }^{68}$ A se considerar o conteúdo das decisões judiciais que transitam em julgado, é preciso diferenciar as que apreciam somente questões processuais (decisões "terminativas" ou "de rito"), daquelas cujo comando alcança também (ou somente) questões materiais a envolver as partes (decisões "definitivas" ou "de mérito"). A diferença radica em que os efeitos das decisões terminativas dizem respeito apenas à relação processual respectiva; já os efeitos das decisões de mérito transcendem a esfera da relação processual e acabam por se projetar na própria relação jurídica material polarizada pelos sujeitos processuais. Da diferenciação acima surgem dois tipos de coisa julgada. Fala-se em coisa julgada formal para aludir a toda decisão, independentemente do conteúdo decisório, seja terminativa, seja de mérito, contra a qual não caiba mais recurso. Contudo, esse tipo de coisa julgada só gera efeitos processuais (salvo questões acidentais, como a condenação ao pagamento de despesas processuais). Representa a imodificabilidade da decisão judicial que transitou em julgado, mas apenas com referência à mesma relação processual no curso da qual surgiu. Logo, não impede outro processo judicial a respeito das questões postas a exame, incluindo as já analisadas no processo anterior. Por isso, há autores que veem aí simples manifestação do instituto da preclusão processual, e não verdadeira coisa julgada. Em segundo lugar, a se tratar de uma decisão de mérito, além da coisa julgada formal, o esgotamento das possibilidades de recurso implica, ainda, a chamada coisa julgada material, que imuniza as repercussões da decisão em face da relação jurídica material examinada. Esse o tipo de coisa julgada de que cuida o art. 502 do NCPC ("Denomina-se 
De outro lado, embora conte com proteção constitucional contra a retroatividade normativa (inciso XXXVI do art. 5ㅇ) e até traga importantes repercussões materiais, a coisa julgada não deixa de ser instituto jurídico tipicamente processual e, por isso, se sujeita à conformação legislativa federal (Constituição, art. 22, I, quarta figura). Logo, a proteção dada pelo inciso XXXVI do art. 5o da Constituição está conectada aos limites tanto subjetivos quanto objetivos da coisa julgada, tal como definidos pela legislação processual ${ }^{69}$. Assim, o que tal disposição constitucional proíbe é a retroatividade da redefinição legal dos limites subjetivos e objetivos da coisa julgada, em detrimento de decisões anteriormente transitadas em julgado.

\section{Inconstitucionalidade e coisa julgada}

Como se viu, a inconstitucionalidade é o nome dado à relação de incompatibilidade que se manifesta entre algum ato ou comportamento e pelo menos uma das normas que utilizáveis como parâmetro de controle da constitucionalidade (bloco de constitucionalidade). Daí não haver dúvidas de que também decisões judiciais, transitadas em julgado ou não, podem apresentar inconstitucionalidades.

Conforme doutrina portuguesa ${ }^{70}$, a coisa julgada merecerá a qualificação "inconstitucional” em qualquer das três situações abaixo: (a) quando o conteúdo da decisão judicial violar diretamente alguma das normas que compõem o bloco de constitucionalidade; (b) quando a decisão judicial proceder à aplicação de algum ato que seja inconstitucional; (c) quando a decisão judicial afastar a aplicação de algum ato, por motivo de inconstitucionalidade, sem que ele fosse mesmo inconstitucional.

Já no direito brasileiro, a questão não é tão simples assim. Isso porque, diferentemente do sistema português, o STF, por política judiciária, optou por reduzir o conceito de inconstitucionalidade somente à desconformidade direta/frontal a uma norma que faz parte do bloco de constitucionalidade. Nessa ordem de ideias, descabe falar em inconstitucionalidade, nem sequer em relação a atos normativos, se, para tanto, o reconhecimento do defeito constitucional tiver de passar, primeiramente, pelo exame de normas infraconstitucionais dotadas de hierarquia superior à do ato analisado ${ }^{71}$. Logo, para o STF, não se trata de verdadeira questão de inconstitucionalidade, mas de simples

coisa julgada material a eficácia, que torna imutável e indiscutível a sentença, não mais sujeita a recurso.").

69 No caso do processo civil, ver, no NCPC, os artigos 503 a 508.

70 Ver OTERO, op. cit., p. 65.

71 Por todos, v. ADIn MC 1.900/DF e ADIn 3.190/GO.

Revista Publicum

Rio de Janeiro, v. 3, n. 1, 2017, p. 307-351.

http://www.e-publicacoes.uerj.br/index.php/publicum

DOI: 10.12957/publicum.2017.29464 
ilegalidade, a antinomia constitucional constatada em atos normativos secundários (decretos, portarias, instruções normativas) editados para regulamentar a execução de atos normativos primários (leis complementares, leis ordinárias, leis delegadas), ainda que estes tenham conteúdo similar ao de alguma norma constitucional ${ }^{72}$.

Daí o problema: se no Brasil a inconstitucionalidade foi reduzida pelo STF só à modalidade frontal ou direta, embora possível enquadrar-se nesta acepção os casos em que a decisão judicial, erradamente, tenha interpretado uma disposição constitucional ou aplicado uma norma da Constituição, tal definição estrita de inconstitucionalidade não alcançaria as hipóteses em que a decisão judicial se limitasse a aplicar efeitos inconstitucionais decorrentes de uma norma infraconstitucional.

E é neste ponto que se mostra importante entender o que, à primeira vista, poderia parecer ocioso - sobretudo a um processualista menos afeiçoado ao direito constitucional - explicar aquelas noções teóricas básicas expostas na primeira parte do trabalho.

Em primeiro lugar, mesmo essa reduzida definição de inconstitucionalidade permite acomodar aqueles mencionados casos em que a decisão judicial "cria" uma norma que não poderia ser obtida pelo critério da dedutibilidade lógica. Assim, se de uma decisão judicial emergir algum comando individual/concreto cujo fundamento partiu da equivocada premissa segundo a qual o dispositivo constitucional $X$ teria o sentido $Z$, quando na verdade o sentido dele era $Y$, tal decisão acaba por tentar introduzir, no sistema jurídico, um comando inovador. E se esse comando equivocado não for reformado pelas vias recursais próprias e transitar em julgado, a coisa julgada passará a apresentar o mesmo vício de inconstitucionalidade que havia na decisão da qual surgiu. Consequentemente, mesmo o conceito reduzido da inconstitucionalidade frontal/direta inclui a inconstitucionalidade da decisão transitada em julgado que extrai uma norma constitucional que nunca pertencera ao sistema jurídico. E semelhante conclusão vale também para os casos em que o juiz, erradamente, interpreta uma disposição

72 Excetuam-se os regulamentos autônomos, i.e., aqueles atos administrativos que não desempenham função meramente regulamentar, já que, devidamente ou não, assumem características de autênticos atos normativos primários. Nesse sentido, são considerados autônomos os regulamentos baixados nos seguintes casos: (a) quando o constituinte dispensa a edição de lei para tratar do assunto versado pelo ato administrativo, fazendo com que este obtenha fundamento de validade diretamente da constituição, como nas hipóteses do decreto previsto no art. 84, VI, "a", com redação da EC 32/2001; ou (b) o ato regulamentar é editado de maneira inválida, sem base constitucional ou legal: (b.1) diante da inexistência de norma primária que seria por ele regulamentada; ou (b.2) em razão da prévia revogação da lei que deveria ser o objeto da regulamentação. 
constitucional e daí utiliza uma norma inexistente para declarar a inconstitucionalidade de uma norma constitucionalmente válida.

Em segundo lugar, já quanto às decisões judiciais que equivocadamente declaram a constitucionalidade de uma norma inconstitucional, é preciso não esquecer que o constituinte estabeleceu uma metanorma específica cuja observância implica a autonomia normativa da coisa julgada, pelo menos no que diz respeito à aplicabilidade do comando individual/concreto emergente da decisão passada em julgado.

Com efeito, ao preservar a coisa julgada até mesmo contra futuras modificações legislativas, o inciso XXXVI do art. 5o da Constituição acabou por ressaltar a autoridade normativa das decisões passadas em julgado, seja em face das normas gerais e preexistentes utilizadas como razão de decidir, seja com relação a normas futuras, tanto de caráter geral quanto individual. Essa ideia fica mais clara quando se percebe, de um lado, que nem a revogação da norma legal aplicada compromete a autoridade da decisão que, passada em julgado, se limitara a aplicar a norma legal revogada; de outro, que inclusive a decisão judicial que haja erroneamente aplicado uma norma legal conserva-se vigente até ser desconstituída pelas vias processuais próprias (v. NCPC, art. 966, V). Assim, tudo leva a crer que a formação da coisa julgada se desprende dos limites lógicos do critério da dedutibilidade e assume normatividade própria, baseada somente no critério da legalidade ${ }^{73}$.

Em resumo, o comando individual/concreto emergente da coisa julgada pertence ao sistema de maneira autônoma. Tudo por força de metanormas do sistema jurídico nacional (sobretudo o inciso XXXVI do art. 5o da Constituição) que determinam a obrigatoriedade da aplicação daquele comando individual/concreto, independentemente da pertinência da norma geral utilizada como razão de decidir. E ainda que não se concorde com essa normatividade própria dos comandos emergentes de decisões judiciais transitadas em julgado, os efeitos jurídicos surgidos a partir do trânsito em julgado têm aplicabilidade garantida por metanorma específica do sistema jurídico (inciso XXXVI do art. 5o da Constituição). Algo suficiente para instaurar relações diretas de

${ }^{73}$ A exposição, neste ponto, aproxima-se da teoria kelseniana, que localiza no princípio da coisa julgada fonte de validade autônoma para decisões judiciais que não se restrinjam à aplicação de normas pré-existentes. Nesse sentido, ao criticar ideias de ESSER, sustentou KELSEN: “A decisão judicial de um caso concreto, a qual não é aplicação de uma norma jurídica geral, materialmente definida, que já esteja em vigor, pode ser influenciada por um princípio da Moral, Política ou Costume, que ainda não influenciou até agora, de nenhum modo, a produção do Direito. A norma individual que representa semelhante decisão judicial pode entrar em vigor em virtude do princípio jurídico-positivo-formal da coisa julgada. Esta força legal jurídico-positiva, a coisa julgada relativa à norma jurídica, não o princípio que é a proposição fundamental da Moral, Política ou Costume, o qual influencia a decisão judicial, é o fundamento de validade desta decisão." (KELSEN, Teoria geral das normas..., p. 146.) 
inconstitucionalidade, mesmo quando a decisão judicial tenha se restringido a reproduzir ou a aplicar comandos retirados de atos normativos infraconstitucionais e preexistentes.

Somente depois de esclarecidas tais peculiaridades é que não há maiores problemas em aderir a teses portuguesas a respeito do assunto, como a de JOÃO DE CASTRO MENDES, para quem, "transitada em julgado, a sentença desprende-se da lei em que se gerou e vale por si mesma, baseada diretamente na Constituição" 74 .

Portanto, para se falar em coisa julgada inconstitucional, basta que o comando emergente de uma decisão judicial passada em julgado implique consequências desconformes às normas integrantes do bloco de constitucionalidade que vigorava no momento em que proferida, não importa se tais consequências provenham diretamente do comando decisório (como no caso de a decisão interpretar erroneamente um preceito da Constituição) ou, indiretamente, seja pela aplicação de ato normativo inconstitucional, seja pela recusa em aplicar ato normativo constitucional, porque indevidamente considerado inconstitucional.

Daí a definição: coisa julgada inconstitucional é o efeito do trânsito em julgado de decisão cujo comando emergente importa na aplicação concreta de consequências jurídicas diversas daquelas decorrentes da linha de deduções lógicas extraídas da interpretação do bloco de constitucionalidade.

\section{Coisa julgada inconstitucional: inexistência ou invalidade?}

Não há consenso sobre se a coisa julgada inconstitucional deva ser considerada juridicamente inexistente ou somente inválida. Porém, boa parte da doutrina sustenta que uma decisão judicial, mesmo que insuscetível de recurso ou remessa necessária, se contrariar a constituição, não passará de um ato "inexistente"

Essa visão é parcialmente equivocada. Como se sustentou acima, a identificação do vício de inexistência de um ato, incluídas as decisões judiciais, não depende simplesmente da hierarquia constitucional da norma que tal ato contrariar. A inexistência é determinada por defeitos relativos à competência lato sensu para produzir o ato ${ }^{76}$. Desse modo, se a decisão "judicial" foi proferida por órgão ou autoridade a quem não é concedida

74 MENDES, João de Castro. Caso Julgado, Poder Judicial e Constituição. Revista da Faculdade de Direito de Lisboa, vol. XXVI, 1985, p. 49, apud OTERO, Ensaio..., p. 45.

75 Por todos, cf. DANTAS, Ivo. Coisa julgada inconstitucional: declaração judicial de inexistência. Fórum Administrativo, Belo Horizonte, n. 15, p. 588-607, mai. 2002; WAMBIER, Teresa Arruda Alvim; MEDINA, José Miguel Garcia. O dogma da coisa julgada: hipóteses de relativização. São Paulo: 2003, p. 34 e segs.

${ }^{76}$ No caso das decisões judiciais, por competência deve-se entender como sendo o núcleo de poder estatal, e não no sentido "processual", a significar a medida da jurisdição.

Revista Publicum

Rio de Janeiro, v. 3, n. 1, 2017, p. 307-351.

http://www.e-publicacoes.uerj.br/index.php/publicum

DOI: 10.12957/publicum.2017.29464 
jurisdição, será mesmo inexistente e nunca poderá redundar em coisa julgada. Afinal, essa decisão, se recomposta às origens, não remeterá a nenhum órgão ao qual a Constituição estabelece poderes jurisdicionais para promulgar decisões do tipo. Exemplo clássico: "sentença" assinada por escrivão ou oficial de justiça ${ }^{77}$.

Contudo, se a decisão judicial tiver sido proferida por alguma autoridade ou órgão investido de jurisdição, não poderá mais ser considerada inexistente. Como se viu, é suficiente à definição da existência de um ato a circunstância de ter sido "promulgado" por autoridade dotada de competência para promulgar atos do mesmo tipo. Daí, ainda que tal ato apresente alguma inconsistência constitucional, o vício implicará invalidade, e não inexistência.

Certo que as ideias de BULYGIN tornariam bem mais consistente e elegante a tese da inexistência (jurídica) da coisa julgada inconstitucional. Coerente com o raciocínio de que só normas gerais devam ser incluídas no catálogo das normas que fazem parte de um sistema jurídico, BULYGIN acaba por dizer que os “juízes só são competentes para promulgar normas que sejam consequência lógica das normas gerais do sistema". ${ }^{78}$ Também coerentemente, BULYGIN defende que, mesmo nos casos excepcionais em que juízes estejam autorizados a criar normas que não decorram de outras preexistentes, 0 processo criativo aí pressuposto radica na estipulação de uma norma geral, na parte de fundamentação decisória, que será então individualmente "aplicada" pelo dispositivo da decisão judicial. Nessa linha, uma decisão judicial que retirasse conclusões logicamente equivocadas da constituição, mesmo que transitasse em julgado, nunca poderia ser considerada existente/pertinente, porque os juízes só disporiam de competência para editar normas individuais extraídas por deduções lógicas das normas já previstas no sistema.

\footnotetext{
77 Nesse sentido, fala FERRAZ JR sobre "a sentença prolatada por alguém que não é juiz, mas que se apresenta como tal, e a sentença de um juiz que, no entanto, não era absolutamente competente para sentenciar sobre determinada matéria. No primeiro caso, a sentença é inexistente, isto é, nunca foi válida. No segundo, ela é nula, ou seja, seus efeitos são desconsiderados desde o início de sua vigência" (Introdução..., p. 212).

78 Nas palavras de BULYGIN: “... es decir, una norma pertenece al sistema, sea porque se deduce de las normas del sistema, sea porque ha sido dictada por una autoridad competente, es el que mejor reconstruye los criterios de pertenencia que los juristas usan efectivamente, aunque bien puede ser que tales usos no sean homogéneos, en el sentido de que respecto de alguna subclase de normas el modelo aplicable sea otro. En particular, Caracciolo sugiere que en el caso de las sentencias judiciales el modelo más adecuado es M3 esto es, el que exige el cumplimiento de ambos criterios, lo que equivaldría a decir que los jueces sólo son competentes para promulgar normas que son consecuencia lógica de las normas generales del sistema (más la descripción del caso). Esto suena bastante razonable, y es un argumento en favor de no mezclar las normas generales con las normas individuales." (Algunas..., p. 261-262.)
} 
Contudo, como se viu, o caráter criativo das normas jurídicas instituídas em sentenças judiciais não depende da natureza geral das normas a partir das quais os juízes fundamentam seus comandos individuais, nem só da observância do critério geral da legalidade, representado pela competência (poder jurisdicional) concedida aos juízes para integrar lacunas ou resolver conflitos entre normas. Dependerá, ainda, da insuficiência do critério da dedutibilidade lógica para extrair a norma aplicada na sentença. Assim, quando obedecem a ambos os critérios de extração de normas pertencentes ao sistema jurídico (critério da legalidade e critério da dedutibilidade lógica), os juízes nada criam ao emitir sentenças individuais.

Ocorre que, como também já foi visto, todas essas questões acerca do papel criativo das decisões judiciais ficam relegadas a segundo plano, no Brasil, em razão da metanorma constitucional que garante a aplicação do comando judicial transitado em julgado.

Enfim, a decisão judicial existente, embora constitucionalmente inválida, surtirá efeitos jurídicos e deverá ser aplicada, por força de garantia constitucional do inciso XXXVI do art. 5ㅇ, até ser desconstituída por outra decisão judicial. E mesmo que tal desconstituição geralmente se faça com eficácia retrospectiva (ex tunc), se isso não for providenciado a tempo e modo devidos, a inconsistência constitucional ficará definitivamente consolidada.

\section{Posição do STF}

Pela jurisprudência do STF, também não se pode considerar "inexistente" a coisa julgada inconstitucional. Por diferenciar, implicitamente, a inconstitucionalidade da inexistência, o Tribunal há muito tem decidido que os efeitos da coisa julgada são imunes à declaração de inconstitucionalidade proferida em outros processos ${ }^{79}$. Para a Suprema Corte, ademais, a coisa julgada inconstitucional não é concretamente atingida nem se a inconstitucionalidade tiver sido reprimida, com eficácia geral (erga omnes), por meio de resolução do Senado Federal ${ }^{80}$, tampouco mediante decisão proferida em ações diretas de inconstitucionalidade ${ }^{81}$.

79 Por todos, cf. Rcl 148/RS, Pleno, rel. Min. MOREIRA ALVES, DJU de 17-06-1983, p. 8.957; Al (AgRg) 145.589/RJ, Pleno, rel. Min. SEPÚLVEDA PERTENCE, DJU de 24-06-1994, p. 16.652; e RE 187.376/PR, 1a Turma, rel. Min. SYDNEY SANCHES, DJU de 13-09-1996, p. 33.241.

80 Nesse sentido, acerca de suspensões determinadas por resolução do Senado Federal, cf. RMS 17.976/SP, 3a Turma, rel. Min. AMARAL SANTOS, DJU de 24-09-1969; e RE 86.056/SP, 1a Turma, Rel. Min. RODRIGUES ALCKMIN, DJU de 1\%/07/77. Também no RE 89.108/GO (rel. Min. CUNHA PEIXOTO, j. em 28-8-80, DJU de 19-12-80), o Plenário da Corte entendeu necessária a ação rescisória para 
Segundo o STF, mesmo que a inconstitucionalidade tenha sido reconhecida com efeitos erga omnes, faz-se necessário desconstituir os efeitos da sentença contrária pelas vias processuais próprias ${ }^{82}$, o que não pode ser obtido reflexamente, sequer em sede de recurso extraordinário interposto contra a execução do título executivo inconstitucional ${ }^{83}$.

Na mesma linha, mais recentemente, no AgRg no RE 594.350/RS (2 a Turma do STF), todos os quatro Ministros que votaram em seguida ao relator, Ministro CELSO DE MELLO, concordaram com o entendimento segundo a qual "não se revela processualmente ortodoxo nem juridicamente adequado, muito menos constitucionalmente lícito, pretender-se o reconhecimento da inexigibilidade de título judicial, sob pretexto de que a

desconstituir acórdão do TJGO que aplicara dispositivo considerado posteriormente inconstitucional pelo STF e que teve eficácia depois suspensa por força de resolução do Senado Federal.

${ }^{81}$ AgRg no RE 473.715/CE, 1a Turma, rel. Min. CARLOS BRITTO, j. em 26-4-2007, DJU de 25-05-2007, p. 75. Tratava-se de recurso extraordinário interposto contra acórdão que julgara improcedentes embargos à execução fundada em título executivo que determinava a aplicação de dispositivo cuja inconstitucionalidade havia sido liminarmente declarada na ADIn MC 1.187/DF e, definitivamente, no RE 247.866/CE. Entendeu a Corte que a coisa julgada, ainda que inconstitucional, não poderia ser desconstituída sequer em sede de recurso extraordinário interposto contra a respectiva execução, pois a parte interessada deveria valer-se dos meios próprios para impugná-la.

$82 \mathrm{E}$ esse entendimento não se considera incompatível nem sequer diante de uma extensão das hipóteses de cabimento de rescisória recentemente adotada pelo STF no AgRg na Rcl 2.600/SE (rel. Min. CEZAR PELUSO, j. em 14-9-2006, DJU de 3-8-2007), julgamento em que a Corte debateu se a decisão de mérito proferida em ADIn legitima rescisão de acórdão proferido em conformidade com medida liminar concedida no mesmo processo, mas em sentido oposto. Na ementa do acórdão do TJSE que negara procedência à rescisória, constou que a "mudança de interpretação, ainda que proferida no âmbito do STF, mesmo em sede de ADIn, não rende ensejo à declaração de violação literal dos dispositivos invocados, quando a postura adotada no acórdão fustigado pela rescisória, mesmo em contradição com o julgamento da ADIn, era escorada em liminar do STF proferida em sede de controle concentrado de constitucionalidade, mormente se cuidando do mesmo processo." Porém, o STF entendeu que, embora a coisa julgada não seja automaticamente atingida pelo efeito vinculante em contrário que decorra de uma decisão posterior, se após a decisão vinculante veio a ser ajuizada ação rescisória, o julgamento desta estará vinculado pelo sentido daquela. Segundo o STF, "a eficácia ex tunc da decisão proferida em controle abstrato torna legítima ação rescisória de sentença que, mesmo anterior àquela decisão, Ihe seja contrária." Assim, de acordo com o precedente em destaque, o princípio da máxima efetividade das normas constitucionais e a consequente prevalência da orientação fixada pelo STF vinculam o julgamento no sentido da rescisão do acórdão conflitante, ainda que este tenha transitado em julgado anteriormente à decisão vinculante. Certo, esse raciocínio acaba por consagrar a curiosa tese segundo a qual a violação de que trata o inciso $V$ do art. 485 do CPC/1973 (atual inciso V do art. 966 do NCPC) não é só aquela que contraria as interpretações constitucionais do STF em vigor no momento da prolação da decisão rescindenda, pois também inclui a violação às interpretações que o STF só tenha feito ou tornado evidente no futuro, i.e, após o julgamento que se pretenda rescindir. Entretanto, como se pode claramente perceber, o que no caso ocorreu não foi a desconstituição retroativa da coisa julgada por força da decisão final da ADIn, senão a repercussão atual dos efeitos vinculantes que desta decorrem em face de julgamento (da rescisória) ocorrido em momento que tais efeitos já deveriam ser observados, ainda que para desconstituir julgamento anterior (do acórdão rescindendo).

${ }^{83}$ AgRg no RE 473.715/CE, 1a Turma, rel. Min. CARLOS BRITTO, j. em 26-4-2007, DJU de 25-5-2007, p. 75. 
sentença transitada em julgado fundamentou-se em lei declarada inconstitucional pelo Supremo Tribunal Federal" ${ }^{84}$.

Tudo isso revela que a inconstitucionalidade da coisa julgada, pela jurisprudência do STF, nunca foi sinônimo de inexistência, bem como que a decisão inconstitucional, mesmo que tecnicamente inválida, uma vez transitada em julgado, será eficaz até que desconstituída pelas vias próprias. Também para o STF, ainda que inconstitucional determinada coisa julgada, não haverá mais como desfazer-Ihe os efeitos que tenha produzido, se já inviabilizada a utilização dos meios impugnativos para atacá-la.

Recentemente, aliás, no RE 730.462/SP ${ }^{85}$, com repercussão geral reconhecida, o Plenário do STF aprovou a tese segundo a qual a "decisão do Supremo Tribunal Federal declarando a constitucionalidade ou a inconstitucionalidade de preceito normativo não produz a automática reforma ou rescisão das decisões anteriores que tenham adotado entendimento diferente. Para que tal ocorra, será indispensável a interposição de recurso próprio ou, se for o caso, a propositura de ação rescisória própria, nos termos do art. 485 do CPC, observado o respectivo prazo decadencial (art. 495)" 86.

Ainda mais novo é o precedente firmado nos ED no AgRg nos EmbDiv nos ED no RE 589.513/RS (j. em 17-3-2016), no qual o Plenário do STF decidiu:

84 2a Turma, j. em 3-4-2012. Igualmente, o julgamento do AgRg no RE 592.912/RS (rel. Min. CELSO DE MELLO, j. em 3-4-2012), de cuja ementa constou: “A sentença de mérito transitada em julgado só pode ser desconstituída mediante ajuizamento de específica ação autônoma de impugnação (ação rescisória) que haja sido proposta na fluência do prazo decadencial previsto em lei, pois, com o exaurimento de referido lapso temporal, estar-se-á diante da coisa soberanamente julgada, insuscetível de ulterior modificação, ainda que o ato sentencial encontre fundamento em legislação que, em momento posterior, tenha sido declarada inconstitucional pelo Supremo Tribunal Federal, quer em sede de controle abstrato, quer no âmbito de fiscalização incidental de constitucionalidade. - A superveniência de decisão do Supremo Tribunal Federal, declaratória de inconstitucionalidade de diploma normativo utilizado como fundamento do título judicial questionado, ainda que impregnada de eficácia ex tunc - como sucede, ordinariamente, com os julgamentos proferidos em sede de fiscalização concentrada (RTJ 87/758 - RTJ 164/506-509 - RTJ 201/765) -, não se revela apta, só por si, a desconstituir a autoridade da coisa julgada, que traduz, em nosso sistema jurídico, limite insuperável à força retroativa resultante dos pronunciamentos que emanam, in abstracto, da Suprema Corte."

85 Julgamento de 28-5-2015.

${ }^{86}$ Dispositivos referentes ao CPC de 1973. No mesmo RE 730.462/SP, o STF ressalvou da exigência de ação rescisória "a questão relacionada à execução de efeitos futuros da sentença proferida em caso concreto sobre relações jurídicas de trato continuado". Essa ressalva, contudo, só parece justificável caso a decisão do STF conflitante com a coisa julgada tiver sido preferida no âmbito do controle abstrato de constitucionalidade. É que, nessa hipótese, dados os efeitos vinculantes da decisão superveniente do STF, o juízo da execução se verá automaticamente impedido de dar sequência a execuções judiciais divergentes. Logo, como já se defendera em sede doutrinária (BERNARDES, Juliano Taveira. Controle abstrato de constitucionalidade: elementos materiais e princípios processuais. São Paulo: Saraival 2004, p. 77), a exemplo do $§ 79$ da Lei Orgânica do Tribunal Constitucional da Alemanha, que remete ao $\S 767$ do CPC daquele país, o efeito vinculante das decisões proferidas em controle abstrato obsta o seguimento das execuções de títulos judiciais em sentido divergente, mas não garante a automática reversão dos pagamentos já efetuados anteriormente. 


\begin{abstract}
"A sentença de mérito transitada em julgado só pode ser desconstituída mediante ajuizamento de específica ação autônoma de impugnação (ação rescisória) que haja sido proposta na fluência do prazo decadencial previsto em lei, pois, com o exaurimento de referido lapso temporal, estar-se-á diante da coisa soberanamente julgada, insuscetível de ulterior modificação, ainda que $o$ ato sentencial encontre fundamento em legislação que, em momento posterior, tenha sido declarada inconstitucional pelo Supremo Tribunal Federal, quer em sede de controle abstrato, quer no âmbito de fiscalização incidental de constitucionalidade."
\end{abstract}

Daí a conclusão: também pela jurisprudência do STF, a coisa julgada inconstitucional não se confunde com um ato inexistente e, embora se deva considerá-la inválida, a autoridade que dela emerge se mantém aplicável enquanto a decisão passada em julgado não for desconstituída, pelos meios processuais próprios, no tempo e modo devidos.

\title{
5. Princípios constitucionais aplicáveis em matéria de
}

\section{desconstituição de coisa julgada inconstitucional}

Ainda que o trânsito em julgado represente a imutabilidade da decisão judicial, os sistemas jurídicos em geral costumam prever meios de impugnação da coisa julgada. No Brasil, não é diferente.

Certo que, por aqui, nem emenda constitucional pode validamente desconstituir a autoridade da coisa julgada com efeito retroativos ${ }^{87}$, algo incomum no direito comparado. Mesmo assim, o legislador federal reúne competência suficiente para instituir e disciplinar mecanismos processuais voltados à desconstituição dos efeitos de decisões judiciais passadas em julgado ${ }^{88}$, desde que não o faça de maneira retroativa, alcançando decisões passadas em julgado anteriormente. Em outras palavras, a despeito de o constituinte

87 Ainda que se possa entender que a expressão "lei", contida no inciso XXXVI do art. 5o da Constituição, não inclua as emendas constitucionais, a proteção dada à coisa julgada vale contra tanto o legislador quanto para o constituinte originário, pois a matéria faz parte do núcleo essencial da própria separação dos Poderes (inciso III do $\S 4$ o do art. 5o da CF/88). Nesse sentido, v. BERNARDES, Juliano Taveira. Efeitos das normas constitucionais no sistema normativo brasileiro. Porto Alegre: Sergio Antonio Fabris, 2002, p. 70-71.

88 Como ensina JOSÉ AFONSO DA SILVA: "A proteção constitucional da coisa julgada não impede, contudo, que a lei preordene regras para a sua rescisão mediante atividade jurisdicional. Dizendo que a lei não prejudicará a coisa julgada, quer-se tutelar esta contra atuação direta do legislador, contra ataque direto da lei. A lei não pode desfazer (rescindir ou anular ou tornar ineficaz) a coisa julgada. Mas pode prever licitamente, como o fez o art. 485 do Código de Processo Civil, sua rescindibilidade por meio da ação rescisória." (Curso de direito constitucional positivo. 6ạ ed. São Paulo: Revista dos Tribunais, 1990, p. 376.)

Revista Publicum

Rio de Janeiro, v. 3, n. 1, 2017, p. 307-351.

http://www.e-publicacoes.uerj.br/index.php/publicum

DOI: 10.12957/publicum.2017.29464 
haver protegido a coisa julgada (art. 5ํ, XXXVI), não inibiu "o Estado de definir, em sede meramente legal, as hipóteses ensejadoras da invalidação da própria autoridade da coisa julgada" 89 .

Óbvio, entretanto, tais mecanismos invalidatórios da coisa julgada são excepcionais. Do contrário, a própria finalidade jurisdicional de estabilizar relações sociais ficaria comprometida caso as decisões judiciais transitadas em julgado pudessem, com facilidade, ser alvo de novas e indefinidas discussões. Acerca do assunto, além do princípio da segurança jurídica, incidem dois outros princípios constitucionais.

Em primeiro lugar, cabem referências ao princípio da reserva da jurisdição em matéria de revisão de decisões judiciais. Isso porque faz parte da própria definição da função jurisdicional do Estado a característica segundo a qual, salvo exceções postas pelo constituinte originário ${ }^{90}$, decisões judiciais não podem ser revistas por quem exerça outro tipo de função estatal (Poderes Legislativo ou Executivo). Daí, mesmo que o legislador seja competente para dispor sobre as modalidades de impugnação à coisa julgada, inclusive para ampliá-las, não poderá incluir quaisquer delas na esfera de competência de órgãos estranhos ao Judiciário.

Em segundo lugar, sobressai o princípio da hierarquia jurisdicional ${ }^{91}$. Diante do esquema hierárquico de distribuição de competências jurisdicionais previsto na Constituição Federal, o legislador não pode atribuir a um órgão judicial inferior poderes para desconstituir decisões proferidas por órgãos superiores. A desconstituição da coisa julgada só pode ser obtida como consequência de decisões emanadas por órgão/autoridade judicial de hierarquia igual ou superior àquele que proferiu, em última instância, a decisão que transitou em julgado.

\footnotetext{
89 STF, Pleno ED na AR 1.279/PR, rel. Min. CELSO DE MELLO, DJU de 13-9-2002.

90 Parecem ser as únicas exceções constitucionais a permitir a desconstituição da coisa julgada por ato proveniente de órgão não jurisdicional: (a) leis penais benéficas são retroativas (art. 5o, $\mathrm{XL}$ ) e, por isso, poderão desconstituir decisões judiciais que aplicaram legislação mais severa, independentemente da data de trânsito em julgado; (b) o princípio da retroatividade da norma penal benéfica estende-se às leis concessivas de anistia, sejam as criminais, sejam as de outras categorias (art. 22, XVII, c/c art. 48, VIII e $\S 60$ do art. 150), o que possibilita desconstituir a coisa julgada; (c) o decreto legislativo de que trata o § 3어 do art. 62 da Constituição, com redação da EC $n$. $32 / 2001$, ao regular os efeitos da rejeição de medida provisória, tem força suficiente para desconstituir decisões judiciais que aplicaram a medida provisória rejeitada, incluindo as decisões já passadas em julgado; (d) o exercício da prerrogativa presidencial de conceder indulto (art. 84, XII), instituto que abrange tanto a graça quanto a comutação de penas, também poderá desconstituir a coisa julgada.

${ }^{91}$ Referido princípio já foi reconhecido pelo STF no julgamento de questão de ordem na Petição $\mathrm{n}$. 3.211/DF (rel. designado Min. MENEZES DIREITO, j. em 13-3-2008, DJ-e de 26-06-2008). Nesse precedente, mesmo à fala de disposição constitucional expressa, o Plenário decidiu ser sua competência a para julgar ação por ato de improbidade administrativa ajuizada contra Ministro do STF, ao argumento de que "distribuir competência para juiz de 1으 grau para julgamento de ministro da Corte quebraria o sistema judiciário como um todo" (Informativo STF, n. 498/2008).
} 


\section{V - Instrumentos de desconstituição da coisa julgada} inconstitucional no processo civil brasileiro: breves

\section{comentários}

\section{Sistema anterior ao NCPC}

Para quem defenda ser a coisa julgada inconstitucional um ato inexistente, uma decisão judicial, mesmo que transitada em julgado, se contrariar a constituição, poderá ser impugnada tanto pelas vias normais de desconstituição (sobretudo a ação rescisória) quanto por meio de ações outras, como a ação declaratória de inexistência da sentença ("querela nullitatis"), ou ainda por simples petição nos autos em que título judicial se constituíra.

Todavia, como detalhado acima, a sentença transitada em julgado não pode ser assim confundida com algum ato inexistente. Por isso, enquanto não for nulificada pelos meios especiais de impugnação judicial, reveste-se da autoridade conferida pelo sistema jurídico à coisa julgada. Sem margem à utilização daqueles tipos mais elásticos de expedientes para simplesmente "declarar" a inexistência da sentença.

Porém, o próprio sistema jurídico prevê vários instrumentos de impugnação à coisa julgada inconstitucional. No que interessa, no âmbito do processo civil, o mecanismo tradicional de desconstituição da coisa julgada é a ação rescisória.

\subsection{Ação rescisória}

No CPC de 1973, o fundamento da ação rescisória contra a coisa julgada inconstitucional estava no inciso $\mathrm{V}$ do art. 485, que permitia rescindir a sentença de mérito que, embora transitada em julgado, violasse "literal disposição de lei". Nesse sentido, interpretava-se a expressão "lei" numa acepção ampla, de modo a alcançar, a fortiori, as violações a normas não somente legislativas, como também da própria Constituição Federal.

Aliás, a demonstrar a grande preocupação com a coisa julgada inconstitucional, o Plenário do STF sempre entendera que a Súmula 343 da Corte $^{92}$ não se aplicava à ação rescisória que estivesse fundamentada em violação literal de dispositivo da Constituição ${ }^{93}$.

92 "Não cabe ação rescisória por ofensa a literal disposição de lei, quando a decisão rescindenda se tiver baseado em texto legal de interpretação controvertida nos tribunais".

${ }_{93} \operatorname{Ver}$ AR 1.478/RJ, AR 1.527/RJ, AR 1.409/SC, ED no RE 328.812/AM, entre outros julgados.

Revista Publicum

Rio de Janeiro, v. 3, n. 1, 2017, p. 307-351.

http://www.e-publicacoes.uerj.br/index.php/publicum

DOI: 10.12957/publicum.2017.29464 
Para o STF, “a manutenção de decisões das instâncias ordinárias divergentes da interpretação adotada pelo STF revela-se afrontosa à força normativa da Constituição e ao princípio da máxima efetividade da norma constitucional". Daí por que caberia "ação rescisória por ofensa à literal disposição constitucional, ainda que a decisão rescindenda tenha se baseado em interpretação controvertida, ou seja, anterior à orientação fixada pelo Supremo Tribunal Federal" (ED no RE 328.812/AM, com repercussão geral) ${ }^{94}$.

Há pouco tempo, contudo, essa jurisprudência foi atenuada. Pelo menos em relação às rescisórias fundadas no descumprimento de disposição constitucional cuja interpretação tenha sido alvo de mudança jurisprudencial do STF ocorrida após a decisão impugnada.

No RE 590.809/RS ${ }^{95}$, o Plenário da Corte não admitiu rescisória em que se pretendia ajustar, à posterior mudança de entendimento do STF (que passara a julgar pela constitucionalidade do ato normativo impugnado), acórdão prolatado segundo entendimento contrário, predominante na jurisprudência da Corte à época. Para tanto, reputou-se que a rescisória não se confundia com algum mecanismo de uniformização da jurisprudência, razão pela qual deveria ser reservada a "situações excepcionalíssimas", ante "a natureza de cláusula pétrea conferida pelo constituinte ao instituto da coisa julgada". Assim, mesmo em matéria constitucional, o cabimento da Súmula 343 não poderia ser afastado "aprioristicamente".

De notar, porém, essa orientação firmada no RE 590.809/RS não se aplica às rescisórias fundadas em mudança jurisprudencial do STF dotada de efeito vinculante, ainda que a nova jurisprudência repute constitucional a norma que era anteriormente tida por inconstitucional. Por isso mesmo, na ementa do RE 509.809/RS, ficou consignado que a Súmula 343 deveria ser observada nas situações em que, "inexistente controle concentrado de constitucionalidade", houvesse "entendimentos diversos sobre o alcance da norma, mormente quando o Supremo tenha sinalizado, num primeiro passo, óptica coincidente com a revelada na decisão rescindenda."

\subsection{Embargos/impugnação rescisórios à execução}

94 Tribunal Pleno, rel. Min. GILMAR MENDES, j. em 6-3-2008.

95 Julgamento de 22-10-2014. Em sentido similar, no julgamento da AR 2.199/SC, o Pleno do STF decidiu que não "cabe ação rescisória de decisões proferidas em harmonia com a jurisprudência do STF, ainda que ocorra alteração posterior do entendimento do Tribunal sobre a matéria" (j. em 23-42015). 
Por outro lado, a partir de 2000, o sistema processual brasileiro passou a contar com novo instrumento de impugnação da coisa julgada inconstitucional. Cuida-se dos chamados embargos "rescisórios" à execução, bem como da congênere impugnação "rescisória" à execução, cuja procedência subtrai a eficácia executória da coisa julgada inconstitucional, mas sem desconstituí-la propriamente.

Novidades instituídas pela MP 1.984-17/2000 e suas reedições, foram também tratadas pela Lei 11.232/2005, que admitiu - por motivo de inexigibilidade do título exequendo - a apresentação de impugnação à execução (e de embargos à execução) de "título judicial fundado em lei ou ato normativo declarados inconstitucionais pelo Supremo Tribunal Federal, ou fundado em aplicação ou interpretação da lei ou ato normativo tidas pelo Supremo Tribunal Federal como incompatíveis com a Constituição Federal" (ver $\S 1$ o do art. 475-L incluído no CPC/1973, bem como o parágrafo único acrescentado ao artigo 741 do CPC/1973).

A constitucionalidade desses novos instrumentos, porém, sempre foi polêmica, sobretudo em razão da suposta violação da garantia de intangibilidade da coisa julgada (Constituição, art. 5으, XXXVI) ${ }^{96}$.

96 O trecho a seguir, publicado em livro de 2004, ilustra bem os problemas da inovação: “(...) o STF sempre considerou os efeitos da coisa julgada imunes à declaração de inconstitucionalidade proferida em outros processos, a despeito da eventual suspensão erga omnes do ato normativo em que se tenha baseado a decisão irrecorrível. Contudo, a partir de reedições da Medida Provisória 1.984-17, de 4-5-2000 (atual MP 2.180-35, de 24-8-2001), pretende-se mitigar o efeito da coisa julgada, mediante a criação dos embargos à execução lastreados na inexigibilidade do 'título judicial fundado em lei ou ato normativo declarados inconstitucionais pelo Supremo Tribunal Federal ou em aplicação ou interpretação tidas por incompatíveis com a Constituição Federal.'

Assunto dos mais debatidos, essa novidade representa indireta superação do prazo decadencial da ação rescisória. No entanto, sua constitucionalidade pressupõe exames da mais alta importância. Em primeiro lugar, porque o veículo normativo escolhido não satisfaz o requisito da urgência que se exige para editar medidas provisórias, dado o caráter estável da coisa julgada. Aqui, reparar que esse vício formal também contamina a futura lei de conversão da medida provisória. Em segundo lugar, é imprescindível saber até que ponto o núcleo essencial do princípio constitucional da segurança jurídica, que fundamenta a estabilidade do efeito de coisa julgada, pode ser mitigado pela lei em favor de outros princípios constitucionais. Em terceiro lugar, diante do esquema hierárquico de distribuição de competências na $\mathrm{CF} / 88$, importa ainda analisar se o legislador tem margem de liberdade suficiente para, em termos assim drásticos, deferir a órgão de primeiro grau poderes para desconsiderar os efeitos da coisa julgada material proveniente de acórdãos de instâncias judiciais superiores.

De outro lado, a decisão judicial transitada em julgado não é ineficaz ou tampouco inexistente só porque a jurisprudência constitucional do STF se fixou de modo diverso. Logo, parece que só um efeito processual conducente à vinculação dos demais órgãos do Judiciário pode justificar o pretendido bloqueio da execução de decisões irrecorríveis; não, porém, um efeito reflexo de acórdãos desprovidos de efeito vinculante. Destarte, caso se aceite a tese da ineficácia processual dos julgados colidentes com as decisões de controle de constitucionalidade abstrato dotadas de efeito vinculante, a inovação normativa poderia ser então interpretada conforme à Constituição. Assim, o parágrafo único do art. 741 do CPC seria entendido como hipótese a complementar aquela prevista no inciso II do mesmo artigo, com a diferença de viabilizar embargos à execução mesmo quando a inexigibilidade do título, por força do efeito vinculante, ocorrer após o trânsito em julgado

Revista Publicum

Rio de Janeiro, v. 3, n. 1, 2017, p. 307-351.

http://www.e-publicacoes.uerj.br/index.php/publicum

DOI: $10.12957 /$ publicum.2017.29464 
Ao tempo do CPC/1973, porém, o STF nunca chegara a declarar, expressamente, a inconstitucionalidade dos dispositivos que veicularam esses novos expedientes rescisórios. Contudo, tudo indicava que o STF faria isso em breve.

Nesse sentido, no AgRg no RE 594.350/RS e no AgRg no RE 592.912/RS, a 2a Turma concordara, à unanimidade, com o voto do Min. CELSO DE MELLO, para quem "não se revela processualmente ortodoxo nem juridicamente adequado, muito menos constitucionalmente lícito, pretender-se o reconhecimento da inexigibilidade de título judicial, sob pretexto de que a sentença transitada em julgado fundamentou-se em lei declarada inconstitucional pelo Supremo Tribunal Federal." Em julgamento referente à constitucionalidade dos embargos à execução previstos no $\S 5$ o do art. 884 da CLT (dispositivo semelhante ao art. 741 do CPC), no RE 590.880/CE (Plenário), quatro dos sete votos já proferidos o foram no sentido da inconstitucionalidade do preceito ${ }^{97}$. Ademais, no $\operatorname{RE} 730.462 / S P$ (j. em 28-5-2015), com repercussão geral reconhecida, embora sem declarar a inconstitucionalidade do parágrafo único do art. 741 do CPC, o Plenário do STF aprovou a tese segundo a qual a "decisão do Supremo Tribunal Federal declarando a constitucionalidade ou a inconstitucionalidade de preceito normativo não produz a automática reforma ou rescisão das decisões anteriores que tenham adotado entendimento diferente. Para que tal ocorra, será indispensável a interposição de recurso próprio ou, se for o caso, a propositura de ação rescisória própria, nos termos do art. 485 do CPC, observado o respectivo prazo decadencial (art. 495)". No mesmo RE 730.462/SP, porém, o STF ressalvou da exigência de ação rescisória "a questão relacionada à execução de efeitos futuros da sentença proferida em caso concreto sobre relações jurídicas de trato continuado" ${ }^{\prime 98}$.

da decisão exequenda. De todo modo, a exemplo do direito alemão, o efeito vinculante não implica a reversão das já implementadas anteriormente. Além disso, na forma do art. 5o, XXXVI, da CF/88, o novo tipo de embargos não se pode aplicar contra decisões transitadas em julgado antes da medida provisória pela qual foi criada." (BERNADES, Juliano Taveira. Controle abstrato de constitucionalidade: elementos materiais e princípios processuais. São Paulo: Saraiva, 2004, p. 7577.)

97 O julgamento prosseguiu e, em 1-6-2016, a votação ficou empatada em cinco a cinco. Daí, o Ministro RICARDO LEWANDOWSKI (Presidente) indicou adiamento, para proferir o voto de desempate após melhor exame da matéria.

${ }^{98}$ Essa ressalva, contudo, só parece justificável caso a decisão do STF conflitante com a coisa julgada tiver sido preferida no âmbito do controle abstrato de constitucionalidade. É que, nessa hipótese, dados os efeitos vinculantes da decisão superveniente do STF, o juízo da execução se verá automaticamente impedido de dar sequência a execuções judiciais divergentes. Logo, como já se defendeu em sede doutrinária (BERNARDES, Controle..., p. 77), a exemplo do § 79 da Lei Orgânica do Tribunal Constitucional da Alemanha, que remete ao $\S 767$ do CPC daquele país, o efeito vinculante das decisões proferidas em controle abstrato obsta o seguimento das execuções de títulos judiciais em sentido divergente, mas não garante a automática reversão dos pagamentos já efetuados anteriormente. 
Não bastasse, um dia antes do início da vigência do NCPC, nos ED no AgRg nos EmbDiv no ED no RE 589.513/RS ${ }^{99}$, o Plenário do STF recusou aplicação aos embargos rescisórios previstos no parágrafo único do art. 741 do CPC/1973. Em julgamento que deveria implicar a própria declaração de inconstitucionalidade do preceito legal (v. Súmula Vinculante n. 10), mas sem que o tenha feito expressamente, o Plenário da Corte, por unanimidade, acatou voto do relator, Ministro CELSO DE MELLO, para quem se "revelam conflitantes, com a garantia constitucional da res judicata, as regras legais que autorizam a desconsideração da coisa julgada material em face de declaração de inconstitucionalidade (ou de uma nova interpretação constitucional) emanada do Supremo Tribunal Federal, à semelhança do que prescrevem, p. ex., o art. 475-L, § 10, e o art. 741, parágrafo único, ambos do Código de Processo Civil."

\section{Sistema do NCPC}

\subsection{Ação Rescisória}

Pelo NCPC, a coisa julgada inconstitucional também pode ser desconstituída por via da rescisória. $\mathrm{O}$ inciso $\mathrm{V}$ do art. 966 admite o cabimento da ação rescisória contra a decisão transitada em julgado que "violar manifestamente norma jurídica".

Porém, diferentemente do código anterior, não é mais preciso recorrer à interpretação extensiva do termo "lei". Ao prever a rescisória para casos de violação à "norma jurídica", o legislador assegura, automaticamente, a possibilidade de desconstituição da coisa julgada contrária a qualquer norma constitucional (regra ou princípio).

Ademais, ao trocar a expressão "violar literal disposição de lei" pela expressão "violar manifestamente norma jurídica", o legislador torna claro o cabimento da rescisória fundamentada na violação de normas constitucionais implícitas, i.e, aquelas obtidas a despeito da existência de disposição expressa, tais como o princípio da proporcionalidade.

Entretanto, a mesma expressão legislativa passou exigir que a violação a norma constitucional seja manifesta - i.e., evidente, incontestável. O que parece sempre atrair o entendimento da mencionada Súmula 343 do STF, inclusive nos casos em que a interpretação constitucional tenha se firmado antes da decisão rescindenda.

Quanto ao prazo para a propositura da rescisória, o legislador criou imbróglio desnecessário, que não havia no sistema anterior. O NCPC manteve circunscrito em dois

${ }^{99}$ Rel. Min. CELSO DE MELLO, j. em 17-3-2016. 
anos o prazo normal para ajuizamento da rescisória, a contar do "trânsito em julgado da última decisão proferida no processo" (art. 975, caput). Contudo, previu ainda que, para desconstituição da coisa julgada inconstitucional, o prazo extintivo da ação rescisória "será contado do trânsito em julgado da decisão proferida pelo Supremo Tribunal Federal" ( $§ 15$ do art. 525 e $\S 8$ ㅇ do art. 535 do NCPC). Ou seja, o NCPC não estabeleceu, expressamente, o período máximo dentro do qual a coisa julgada inconstitucional poderá ser questionada a contar da decisão divergente do STF!?

Porém, a falta de definição legislativa do prazo decadencial para esse tipo de rescisória fere o princípio da segurança jurídica e a garantia fundamental da intangibilidade da coisa julgada (art. 5ㅇ, XXXVI, da CF). Daí a aparente inconstitucionalidade material dessa lacuna legislativa quanto ao prazo para propositura da rescisória em destaque.

Por isso mesmo, há quem proponha restringir, pela "regra do $2+2$ ", o prazo decadencial do $\S 15$ do art. 525 e do $\S 8$ o do art. 535 do NCPC. Assim, somente poderia ser iniciado o prazo da rescisória, a partir do trânsito em julgado da decisão do STF, "se ainda não tiver sido extinta a pretensão rescisória cujo prazo tenha-se iniciado do trânsito em julgado da decisão exequenda"100.

Parece mais correto, contudo, utilizar outra diretriz para corrigir essa anomalia material e identificar um prazo máximo à rescisória contra a coisa julgada inconstitucional ${ }^{101}$. Em analogia à regra quinquenal da ação rescisória prevista para o caso de descoberta da prova nova ( $\S 2$ o art. 975 do NCPC), o termo final do prazo de decadência da rescisória também fica limitado em "05 (cinco) anos, contado do trânsito em julgado da última decisão proferida no processo". Logo, embora o prazo da rescisória contra a coisa julgada inconstitucional seja de dois anos (art. 975, caput, do NCPC), porém "contado do trânsito em julgado da decisão proferida pelo Supremo Tribunal Federal", a ação deverá ser proposta dentro do prazo máximo de cinco anos, sob pena de decadência ( $§ 15$ do art. 525 e $\S 80$ do art. 535, c/c § 2 do art. 975 do NCPC).

\subsection{Embargos/impugnação rescisórios à execução}

A exemplo do CPC/1973, para obstar a execução da coisa julgada inconstitucional, o NCPC também prevê o cabimento tanto da impugnação quanto dos embargos rescisórios à

100 Ver NERY JR., Nelson; NERY, Rosa Maria Andrade. Comentários ao Código de Processo Civil. São Paulo: Revista dos Tribunais, 2015, p. 1.039.

101 Nesse sentido: BERNARDES, Juliano Taveira; FERREIRA, Olavo Augusto Alves. Direito constitucional: teoria da constituição. 6. ed. Salvador: JusPodivm, 2016, p. 425-426. 
execução. Todavia, diferentemente da redação dúbia inserida na legislação anterior, a Lei 13.105/2015 garantiu maior autoridade à coisa julgada, mesmo quando esta divergir de decisões proferidas pelo STF no controle abstrato/concentrado de constitucionalidade.

Conforme $\S 12$ do art. 525 e $\S 70$ do art. 535 do NCPC, a impugnação à execução de títulos executivos, sob a alegação de "inconstitucionalidade da coisa julgada", ainda que fundamentada em decisões do STF com efeito vinculante, só terá sucesso se o precedente invocado tiver sido proferido "antes do trânsito em julgado da decisão exequenda"102. Caso contrário, a ineficácia do título executivo dependerá de prévia desconstituição por via de ação rescisória ( $§ 13$ do art. 525 e $\S 8$ o do art. 535 do NCPC).

Por outro lado, ao contrário do que vinha decidindo sob a égide do CPC/1973, o STF acabou por declarar a constitucionalidade desses preceitos invasivos à coisa julgada. Na ADIn 2.418/DF (j. em 4-5-2016), menos de dois meses após o próprio Plenário ter afastado a aplicação dos embargos rescisórios do parágrafo único do art. 741 do CPC/1973 (v. ED no AgRg nos EmbDiv no ED no RE 589.513/RS), o STF surpreendeu.

Muito embora se tratasse de ação direta de inconstitucionalidade movida contra o mesmo parágrafo único do art. 741 do CPC/1973, o Ministro TEORI ZAVASCKI agremiou o voto de todos os outros Ministros presentes - à exceção do Min. MARCO AURÉLIO -, incluindo o do Min. CELSO DE MELLO (então ardoroso defensor da inconstitucionalidade dos embargos rescisórios), e aproveitou para rebater as teses contrárias à invalidade constitucional dos dispositivos semelhantes previstos no NCPC ( $\$ 12$ do art. 525 e $\S 70$ do art. 535 do $\mathrm{NCPC})^{103}$. Para o STF, não há inconstitucionalidade nesses dispositivos do NCPC, pois buscam "harmonizar a garantia da coisa julgada com o primado da Constituição". Razão pela qual "apenas agregariam ao sistema processual brasileiro um

102 Notar que, pelo art. 1.057 do NCPC, o “disposto no art. 525, §§ 14 e 15, e no art. 535, §§ 70 e 8o, aplica-se às decisões transitadas em julgado após a entrada em vigor deste Código, e, às decisões transitadas em julgado anteriormente, aplica-se o disposto no art. 475-L, § 1ㅇ, e no art. 741, parágrafo único, da Lei no 5.869, de 11 de janeiro de 1973.".

103 Conforme constou do Informativo STF n. 824/2016, entendeu a Corte que o instituto da coisa julgada, "embora de matriz constitucional, teria sua conformação delineada pelo legislador ordinário, ao qual seria conferida a faculdade de estabelecer seus limites objetivos e subjetivos, podendo, portanto, indicar as situações em que o instituto cedesse passo a postulados, princípios ou bens de mesma hierarquia, porque também juridicamente protegidos pela Constituição." No entanto, reputou o STF que a inexigibilidade do título executivo a que se referem os dispositivos do NCPC se caracterizaria exclusivamente nas hipóteses em que: (a) a sentença exequenda estivesse fundada em norma reconhecidamente inconstitucional, seja pela aplicação de norma inconstitucional, seja pela aplicação de norma em situação ou com um sentido inconstitucionais; (b) a sentença exequenda tivesse deixado de aplicar norma reconhecidamente constitucional; e (c) desde que, em qualquer dos casos, o reconhecimento dessa constitucionalidade ou a inconstitucionalidade tivesse decorrido de julgamento do STF realizado em data anterior ao trânsito em julgado da sentença exequenda. 
mecanismo com eficácia rescisória de certas sentenças inconstitucionais, em tudo semelhante às hipóteses de ação rescisória".

Nada obstante, ao contrário do que entendeu o STF nesse inusitado precedente, há algo bem diverso nos embargos/impugnação rescisórios em relação à ação rescisória. É que as disposições do $\S 12$ do art. 525 e do $\S 70$ do art. 535 do NCPC permitem ao juiz de primeiro grau subtrair eficácia de títulos judiciais consolidados por obra de quaisquer órgãos jurisdicionais. De modo que o NCPC, originalmente, tampouco o STF, posteriormente, não se atentaram à necessidade de observar o princípio da hierarquia jurisdicional mencionado no item 5 , supra.

Afinal, mesmo que a decisão do STF a embasar a impugnação à execução do título tenha sido proferida antes do trânsito em julgado, o juiz de primeiro grau não deveria poder, ele próprio, desconstituir decisões proferidas por órgãos jurisdicionais superiores. Diante do esquema hierárquico de distribuição de competências estabelecido pela Constituição de 1988, a exemplo do que ocorre na ação rescisória, os órgãos de primeiro grau não parecem dispor de poderes para desconsiderar os efeitos da coisa julgada material proveniente de acórdãos de instâncias judiciais superiores. Logo, o bloqueio da execução de decisões irrecorríveis não surge como simples reflexo de decisões judiciais comuns, mesmo que proferidas pelo STF no controle concreto de constitucionalidade.

A única forma constitucionalmente lícita de utilização dos novos instrumentos de impugnação da coisa julgada é reduzir-lhes a aplicação somente aos casos nos quais a decisão paradigmática do STF (fundamento para impugnar a coisa julgada) tenha sido proferida no âmbito do controle abstrato de constitucionalidade, portanto, dotada de efeito vinculante. Nesses casos, a desconstituição da coisa julgada por juiz de primeiro grau não apresentará anomalia. Afinal, o princípio da hierarquia jurisdicional estará preservado, pois a própria Constituição determina que os demais órgãos do Judiciário (incluindo o juízo da execução) devem observar aquilo que decidido pelo STF, o que implica óbice ao prosseguimento da execução fundada em ato judicial divergente.

Essa conclusão, contudo, reserva novas perplexidades. Isso porque, pelo art. 927 do NCPC, o legislador ordinário tentou atribuir efeitos vinculantes, ainda, aos acórdãos em incidente de assunção de competência ou de resolução de demandas repetitivas e em julgamento de recursos extraordinário e especial repetitivos; aos enunciados das súmulas ordinárias do STF, em matéria constitucional, e do STJ, em matéria infraconstitucional; e até à "orientação" do plenário ou do órgão especial aos quais estiverem vinculados os juízes e tribunais. Entretanto, essa tentativa é flagrantemente inconstitucional. 
Trata-se de alteração radical no sistema de fontes do Direito nacional, porém promovida por simples lei ordinária, algo inadmissível. Esse stare decisis ${ }^{104}$ que o NCPC tenta instituir acaba por atribuir às decisões, súmulas e orientações dos tribunais força vinculante superior àquela conferida às leis em geral. Mais forte que a vinculação que o juiz deve creditar às normas jurídicas será o poder vinculante da interpretação dada pelos tribunais superiores! Os juízes seguem com o poder afastar o cumprimento de leis, sempre que as entenderem inconstitucionais. Mas, contraditoriamente, não poderão desviar-se de precedentes ou de súmulas ordinárias ditadas pelos tribunais aos quais se vinculem.

Certo, não cabe discorrer sobre a (in)conveniência filosófica do stare decisis no direito brasileiro. Entretanto, parece evidente que nenhuma lei "ordinária" poderia validamente implantar esse regime especial de vinculações escalonadas de decisões judiciais, rompendo com a tradição jurídica do civil law estabelecida há séculos no Brasil. A transposição da doutrina alienígena do stare decisis, com a consequente alteração do catálogo de fontes do direito nacional, pressuporia prévia reforma constitucional. Afinal, a atribuição de força vinculante genérica e abstrata a atos judiciais, fora das exceções constitucionais, não se pode dar mediante simples inovações legislativas. Seria preciso, pois, emenda constitucional, a exemplo da concessão de efeito vinculante às decisões proferidas em ações do controle abstrato (EC 3/93) e da criação das súmulas vinculantes $(\text { EC 45/2004) })^{105}$.

Bem verdade que só as "decisões definitivas de mérito" proferidas em ADC dispõem de efeito vinculante expressamente previsto na Constituição ( $§ 20$ acrescido pela EC 3/93 ao art. 102). E isso não impediu o STF de reconhecer efeitos vinculantes, também, às liminares em ADC e às liminares e decisões definitivas de mérito proferidas em ADIn, características decisórias chanceladas na Lei 9.868/99. Ademais, foi o próprio legislador, na Lei 9.882/99, que dispôs sobre o efeito vinculante das decisões tomadas em ADPF. Todavia, essa aparente "ampliação" do efeito vinculante, pelas vias jurisprudencial e

104 Stare decisis é a simplificação da expressão latina "stare decisis et non quieta movere", cujo significado é "estar com as coisas decididas e não mover as coisas quietas." Originária do common law, o sistema jurídico anglo-saxão, a doutrina do stare decisis determina espécie de vinculação de juízes e tribunais inferiores a precedentes julgados por cortes superiores, a menos que o caso em exame apresente peculiaridades a serem identificadas mediante técnicas da distinção (distinguishing).

105 Sobretudo em matéria de controle concreto de constitucionalidade, é ainda mais clara a ilegitimidade do stare decisis implantado no NCPC. Afinal, a Constituição contém dispositivo explícito a condicionar, ao juízo discricionário do Senado Federal, o efeito extensivo das declarações incidentes de inconstitucionalidade proferidas pelo STF (art. 52, X). Sem qualquer margem a que o legislador ordinário pudesse promover outros tipos de vinculações judiciais a precedentes que já não fossem vinculantes por obra do poder constituinte.

Revista Publicum

Rio de Janeiro, v. 3, n. 1, 2017, p. 307-351.

http://www.e-publicacoes.uerj.br/index.php/publicum

DOI: $10.12957 /$ publicum.2017.29464 
legislativa, não parece validar a tentativa do NCPC de instituir o stare decisis no Brasil. É que todos aqueles casos se referem a ações do controle concentrado de constitucionalidade, cujas decisões, à semelhança da exceção criada pela EC 3/93 em relação à $A D C$, têm natural vocação genérica e abstrata. Logo, essa extensão dos efeitos vinculantes se tem por legítima, ainda que por força de autorização implícita do constituinte derivado.

Destarte, em sendo necessária previsão constitucional (ainda que implícita) para estabelecer regime de vinculação a precedentes, a tentativa do NCPC só se mostra legítima - e não sem algum esforço interpretativo - em face das decisões proferidas no âmbito dos recursos extraordinários (RE) aos quais se reconheceu "repercussão geral". Isso porque, bem ou mal, foi o próprio constituinte derivado que atribuiu ao RE índole expansiva e genérica, ao exigir do recorrente a demonstração da "repercussão geral das questões constitucionais discutidas no caso" (§ 3ㅇ do art. 102, na redação da EC 45/2004). Assim, a partir do momento em que o constituinte condicionou a admissão do RE à existência de controvérsia que transcenda o caso concreto, autorizou, implicitamente, que a decisão do STF a julgar tais questões também possa assumir "repercussão geral". Daí ser lícito ao legislador, em princípio, na regulamentação do preceito constitucional, estabelecer mecanismo que vincule os juízes à decisão do STF acerca dessas questões de “repercussão geral”. À semelhança, aliás, do que se viu na Lei 9.882/99, que regulamentou o $\S 1$ 의 do art. 102 da Constituição, atribuindo à ADPF contornos de processo objetivo, com previsão de efeitos vinculantes às respectivas decisões de mérito.

Enfim, em uma interpretação conforme a Constituição deve ser reduzido o alcance normativo do $\S 12$ do art. 525 e do $\S 70$ do art. 535 do NCPC. Salvo nos casos em que a sentença judicial tenha transitado em julgado no próprio 1 grau de jurisdição, a impugnação e os embargos rescisórios à execução só podem atingir a eficácia do titulo judicial se coisa julgada inconstitucional contrariar o efeito vinculante decorrente de decisões finais proferidas pelo STF em ações direta de inconstitucionalidade, em ações declaratórias de constitucionalidade, em arguições de descumprimento de preceito fundamental ou em sede de recurso extraordinário com "repercussão geral" reconhecida.

Mas, antes de encerrar, é preciso ainda dizer que o atual sistema jurídico brasileiro prevê meios diretos de impugnação à coisa julgada inconstitucional não somente no âmbito do controle concreto de constitucionalidade (como a ação rescisória e a impugnação/embargos rescisórios). Muito importante lembrar que, a despeito da atual e 
injustificada resistência do STF ${ }^{106}$, mesmo no âmbito do controle abstrato de constitucionalidade, é possível utilizar a arguição de descumprimento de preceito fundamental (ADPF) para atacar e desconstituir decisões judiciais transitadas em julgado ${ }^{107}$.

\section{Referências bibliográficas}

BARROS, Sérgio Resende de. Constituição, artigo 52, inciso X: reversibilidade? Revista de Informação Legislativa, Brasília, n. 158, p. 233-239, abr./jun. 2003.

BERNARDES, Juliano Taveira. Efeitos das normas constitucionais no sistema normativo brasileiro. Porto Alegre: Sergio Antonio Fabris, 2002.

Controle abstrato de constitucionalidade: elementos materiais e princípios processuais. São Paulo: Saraiva, 2004.

106 O STF ainda não elucidou sequer a devida dimensão do princípio da subsidiariedade previsto no art. 4ํ da Lei 9.882/99. Do Plenário da Corte, há precedentes a entender ora (a) pela ampliação do alcance do princípio, de modo que a existência de qualquer meio judicial eficaz impede a utilização da ADFP (ver AgRg na ADPF 17/AP, bem como na ADPF 3/CE, no AgRg na ADPF 18/CE, na ADPF 12/DF, na ADPF 128/DF, na ADPFMC 157/DF , na ADPFMC 155/PB e na ADPF 53/PI); ora (b) pela restrição da subsidiariedade só aos meios disponíveis no controle abstrato (ADPF 33/PA, ADPFMC 47/PA, ADPF 96/DF, ADPFMC 126/DF, ADPFMC 129/DF e ADPF 101/DF), ainda que feito por meio de ADIn estadual, seja originariamente nos Tribunais de Justiça (ADPFMC 100/TO), seja pela via recursal (interposição de RE contra o acórdão da ADIn estadual: ADPF 111/SC). Por consequência, o STF vinha inadvertidamente negando seguimento a ADPF's autônomas ajuizadas contra decisões transitadas em julgado, simplesmente por entender que a ação não pode ser utilizada "como sucedâneo da ação rescisória" (decisão monocrática do Min. CELSO DE MELLO na ADPFMC 52/MA, DJU de 2-6-2006); não comporta pretensão rescisória (decisão monocrática da Min. ELLEN GRACIE na ADPFMC 69/RJ, DJU de 6-5-2005), já que não "cabe a este instituto desconstituir coisa julgada" (decisão monocrática do Min. RICARDO LEWANDOWSKI na ADPF 134/DF, DJ-e de 10-8-2008), nem pode assumir a função substitutiva de embargos à execução (ADPF 83/ES, Pleno, Informativo STF, n. 503/2008). Mas houve algum avanço na jurisprudência do STF a respeito do assunto. O Plenário da Corte, ao julgar parcialmente procedente pedido formulado na ADPF 101/DF, declarou "inconstitucionais, com efeitos ex tunc, as interpretações, incluídas as judicialmente acolhidas, que permitiram ou permitem a importação de pneus usados de qualquer espécie, aí insertos os remoldados." O avanço radicou em que a decisão desse precedente alcançou não só (a) as decisões pendentes de recurso, como também (b) os efeitos das decisões transitadas em julgado e que já fossem alvo de ação rescisória, com exceção daquelas "cujo conteúdo já tenha sido executado e exaurido seu objeto" (c) decisões judiciais, transitadas em julgado ou não, cujos conteúdos decisórios fossem "abertos" ou "dispostos de forma ilimitada para o futuro".

107 Como dito em obra específica (BERNARDES, Controle..., cit.), a ADPF (em sua modalidade autônoma) deveria ter sempre por alvo uma decisão judicial (transitada em julgado ou não), para tal efeito, identificada como o ato do Poder Público do qual decorre a direta afronta ao preceito fundamental ou que não tenha sido capaz de afastar a lesão praticada por meio de outro comportamento. Nisso, a ADPF é similar à queixa constitucional alemã (Verfassungsbeschwerde) e ao amparo constitucional espanhol, instrumentos que, na prática, se convertem em mecanismos de impugnação exclusiva de decisões judiciais, salvo nos casos em que o ordenamento jurídico não disponibiliza a via judicial. Nessa linha de raciocínio, embora o objeto "imediato" da ADPF radique no ato do qual partiu a concreta lesão ao preceito fundamental (i.e., numa decisão judicial), a constitucionalidade de atos e comportamentos outros é controlada de maneira "mediata" ou "indireta", sob a alegação de que o ato judicial falhou quando lhes deu aplicação ou se negou a reconhecer que descumpriam preceito fundamental.

Revista Publicum

Rio de Janeiro, v. 3, n. 1, 2017, p. 307-351.

http://www.e-publicacoes.uerj.br/index.php/publicum

DOI: 10.12957/publicum.2017.29464 
"Viradas" de jurisprudência do STF e suas repercussões em casos similares. In: NOVELINO, Marcelo (org.) et al. Leituras complementares de direito constitucional: controle de constitucionalidade. 3a ed. ampl. rev. atual. Salvador: JusPodivm, 2010.

BERNARDES, Juliano Taveira; FERREIRA, Olavo Augusto Alves. Direito constitucional: teoria da constituição. 6a ed. Salvador: JusPodivm, 2016.

BULYGIN, Eugenio. Algunas consideraciones sobre los sistemas jurídicos. Doxa. Cuadernos de Filosofía del Derecho, Alicante, n. 9, p. 257-279, 1991.

Los jueces ¿crean derecho? Isonomía: Revista de Teoría y Filosofía del Derecho, Alicante, n. 18, p. 7-25, abr. 2003.

El problema de la validez en Kelsen. In: KELSEN, Hans; BULYGIN, Eugenio; WALTER, Robert. Validez y eficacia del derecho. Buenos Aires: Editorial Astrea, 2005, p. 113.

BULYGIN, Eugenio; MENDONCA, Daniel. Normas y sistemas normativos. Madrid: Marcial Pons, 2005.

CANARIS, Claus-Wilhelm. Pensamento sistemático e conceito de sistema na ciência do direito. Trad. A. Menezes Cordeiro. 3ạ ed. Lisboa: Fundação Calouste Gulbekian. 2002.

DANTAS, Ivo. Coisa julgada inconstitucional: declaração judicial de inexistência. Fórum Administrativo, Belo Horizonte, n. 15, p. 588-607, mai. 2002.

FAVOREU, Louis; RUBIO LLORENTE, Francisco. El bloque de la constitu-cionalidad. Madrid: Civitas, 1991.

FERRAZ JR., Tercio Sampaio. Introdução ao estudo do direito: técnica, decisão, dominação. 3a ed. São Paulo: Atlas, 2001.

FLORES MENDOZA, Imer Benjamín. La concepción del derecho en las corrientes de la filosofía jurídica. Boletín Mexicano de Derecho Comparado, Cidade do México, n. 90, p. 1001-1036, set./dez. 1997.

GUASTINI, Riccardo. Normas supremas. Doxa. Cuadernos de Filosofía del Derecho, Alicante, n. 17-18, p. 257-270, 1995

. Teoria e dogmatica delle fonti. Milano: Giuffrè, 1998.

Estudios de teoría constitucional. (Col. Doctrina Jurídica Contemporánea). Trad. Maria Bono, Perfecto Andrés, José Maria Lujambio, Andréa Greppi e Miguel Cargonell. México: Miguel Cargonell, 2001.

HART, O conceito de direito. 3a ed. Trad. A. Ribeiro Mendes. Lisboa: Fundação Calouste Gulbenkian, 2001.

KELSEN, Hans. Teoria pura do direito. Trad. João Baptista Machado. 6ạ ed. Coimbra: Armênio Amado, 1984. 
Teoria geral das normas. Trad. José Florentino Duarte. Porto Alegre: Sergio Antonio Fabris Editor, 1986.

Teoria geral do direito e do estado. 2a ed. Trad. Luís Carlos Borges. São Paulo: Martins Fontes, 1992.

MEDEIROS, Rui. A decisão de inconstitucionalidade: os autores, o conteúdo e os efeitos da decisão de inconstitucionalidade da lei. Lisboa: Universidade Católica, 1999.

MEIRELLES, Hely Lopes. Direito administrativo brasileiro. 16a ed. atual. São Paulo: Revista dos Tribunais, 1990.

MIRANDA. Jorge. Contributo para uma teoria da inconstitucionalidade. Reimpr. Coimbra: Coimbra Ed., 1996.

MORESO, José Juan; VILAJOSANA, Josep Maria. Introducción a la teoria del derecho. Madrid: Marcial Pons, 2004.

NERY JR., Nelson; NERY, Rosa Maria Andrade. Comentários ao Código de Processo Civil. São Paulo: Revista dos Tribunais, 2015.

NEVES, Marcelo. Teoria da inconstitucionalidade das leis. São Paulo: Saraiva, 1988.

OTERO, Paulo Manuel Cunha da Costa. Ensaio sobre o caso julgado inconstitucional. Lisboa: Lex, 1993.

SILVA, José Afonso. Curso de direito constitucional positivo. 6. ed. São Paulo: Revista dos Tribunais, 1990.

SOUSA, Marcelo Rebelo de. O valor jurídico do acto inconstitucional. Lisboa: [s.n.], 1988.

WAMBIER, Teresa Arruda Alvim; MEDINA, José Miguel Garcia. O dogma da coisa julgada: hipóteses de relativização. São Paulo: 2003.

WEINBERGER, Ota. A philosophical approach to norm logic. Ratio Juris, Bologna, vol. 14, n. 1, p. 130-141, mar. 2001.

ZAVASCKI, Teori Albino. Eficácia das sentenças na jurisdição constitucional. São Paulo: RT, 2001.

Enviado em: 06/07/2017

Aprovado em: 05/08/2017 